\title{
The Travel Behaviour of Polish Women and Adaptation of Transport Systems to Their Needs
}

\author{
Katarzyna Nosal Hoy *D and Sabina Puławska-Obiedowska \\ Department of Transport Systems L-6, Cracow University of Technology, Warszawska 24, 31-155 Krakow, Poland; \\ spulawska@pk.edu.pl \\ * Correspondence: knosal@pk.edu.pl
}

check for updates

Citation: Nosal Hoy, K.;

Puławska-Obiedowska, S. The Travel Behaviour of Polish Women and Adaptation of Transport Systems to Their Needs. Sustainability 2021, 13, 2693. https://doi.org/10.3390/ su13052693

Academic Editor: Armando Cartenì

Received: 31 January 2021

Accepted: 26 February 2021

Published: 2 March 2021

Publisher's Note: MDPI stays neutral with regard to jurisdictional claims in published maps and institutional affiliations.

Copyright: (c) 2021 by the authors. Licensee MDPI, Basel, Switzerland. This article is an open access article distributed under the terms and conditions of the Creative Commons Attribution (CC BY) license (https:/ / creativecommons.org/licenses/by/ $4.0 /)$.

\begin{abstract}
Although knowledge of women's travel behaviours is essential to guarantee equality in transport, there is still a lack of awareness of gender-differentiated behaviour and gender issues are not often incorporated into urban policy. The aim of the article is to present a first attempt at a wider-scale diagnosis of women's travel behaviours and needs as well as existing barriers to transportation access for woman in Poland, with respect to current findings. Documents on history, culture, social factors and labour market data were reviewed to indicate factors that may explain travel behaviours. The data of the Travel Studies for seven Polish cities were analysed to diagnose gender differences in travel. Public policies and initiatives were analysed to examine the level of awareness of women's needs and the adaptation of transport to these needs. The results proved that the greatest differences in the trip purpose was observed for age group 25-49, in which women make more trips for errands, and men for work. Women travel more, which is observed among 25-59-year-olds, if the main occupation is considered. Women travel more on foot and by public transport, while men by private car and the results indicate that it is mostly visible for people aged 25-59. The age groups 39-49 for women and 30-49 for men are the most dependent on the car. The differences may be explained by historical, cultural and social factors, and these factors can be also seen as barriers to achieving equal access to transport. A low level of awareness of women's mobility needs is one of the reasons that Polish transport systems are not fully adapted to their needs.
\end{abstract}

Keywords: gender; travel behaviour; travel needs; labour market; family roles; cultural and historical factors; public policy analysis; barriers in transport access; transport equity; social aspects of transportation

\section{Introduction}

The knowledge of travel behaviours and needs of women and men as well as their determinants is essential to guarantee people's equality in access to goods and services, and gender perspective should be included in the analysis of mobility needs and aims to avoid the creation of barriers and inequalities for women [1]. Meanwhile, in Poland, there is still a lack of awareness of the gender-differentiated behaviour and gender equality issues are not often incorporated into transport policy, planning and provision [2]. It should be noted that Poland is a country with a complicated history-it has gone through three partitions, two world wars and 50 years of communist regime. It was only in 1989 that the country gained full independence and sovereignty while its population gained access to all freedoms and goods. This complicated history shaped the role of Polish women in the family and society as well as their position in the labour market [3-6], which is reflected in travel behaviour. Delayed access to individual goods, including the car, influenced current perception of these goods. The stereotype of a car as an indicator of status and position as well as a masculine attribute is still very much alive in Poland [7]. 
Poland is a country where the percentage of Catholics is $91,9 \%$, [8] and where, for the last few years, the government has been headed by leaders with conservative views on family and religion. The current political situation has brought the political discourse very close to the religious narrative of the Church, deprecating feminist ideas [9]. This is also reflected in the marginalization of the problem of gender equality in development policies and strategies related to spatial planning and transport. The vast majority of these policies do not consider the needs of women as an individual social group or the needs of persons with reduced mobility escorted by women (children, seniors, disabled). It is one of the reasons that Polish women experience difficulties during travel. In case of travel on foot complaints might concern; missing or discontinuous sidewalks, poor condition of sidewalks, cars parked on the sidewalks [10-13], while in case of bike travel-the lack of the bicycle paths and non-cohesive path system [14]. At some places, public transport service quality is still an issue in terms of information, punctuality, cost, security, frequency of operation and travel comfort [2,15-18].

So far, the research on gender in transport conducted in Poland has focused on women's perception on building more a sustainable transport environment [19] and the perception of the quality of public transport among women and men [2]. There has been no research showing the differences in travel behaviour between Polish men and women, which would provide the argument that transport systems must be tailored to the specific needs of women. The extent to which transport policy and transport systems take into account the needs of women has also not been wider analysed.

The aim of the article is to present a first attempt at a wider-scale diagnosis of women's travel behaviours and needs as well as existing barriers to transportation access for woman in Poland, with respect to current findings of other world-wide and European research in this subject. Accounting for the above complexities, the paper intends to answer the following research questions: (1) do the historical, cultural and social factors which have shaped the family roles and women's situation in the Polish labour market explain women's travel behaviour, (2) are there differences in the travel behaviours of women and men within Poland, (3) are these differences the same as in other European countries, (4) is there awareness of women's mobility needs in Poland, and (5) are Polish transport systems adapted to women's needs?

Based on the review of existing publications, reports, documents, and available results of Comprehensive Travel Studies (CTS) carried out in Polish cities, this article indicates various factors that may explain the differences in travel behaviours between women and men. It also examines the source of barriers to transportation access for women, throughout wide analyses of historical, cultural, and social conditions and an analysis of public policies in relation to the level of decision-makers' and planners' awareness of gender differences in travel and adaptation of transport to women's needs. The outcomes of the analyses related to gender travel differences are compared with other existing findings of studies across Europe.

The paper is organized as follows. First, as a background (Section 2), the different current statistics on women's position on labour market and the gender-based allocation of responsibilities within a family at the European level are diagnosed. Then, in respect to these findings, various studies carried out within the world and Europe on differences in travel behaviours between the two genders are presented as a point of comparison. In Section 3, we introduce the methodical issues and the data sources used in the analysis. In Section 4, historical, cultural and social factors influencing socio-economic situation of Polish women in European context are described, which allows a deeper interpretation of the data on the situation of women on the Polish labour market, which is presented and analysed in Section 5. In Section 6, in relation to outcomes of previous socio-economic findings, we analyse and present the results of the CTS surveys conducted in 7 Polish cities to show gender-based differences in trip purpose, number of trips, and transport mode choices. Then, in Section 7, we analyse the level of awareness of women's mobility needs 
in Polish urban policy and adaptation of transport to these needs. The Section 8 includes discussion, while in Section 9, we finalize our conclusions.

\section{Background}

When considering the women's position in the labour market that influences transport behaviours, the following assumption, resulting from historical and social circumstances, should be taken into consideration: women are more likely to be employed in part-time jobs; women are more concentrated in low-wage professions; women and men are involved in different occupations, i.e., women are more employed in care-giving professions and in services; women have less access to private cars [20].

Women's participation in the EU labour markets has been gradually growing, but there is still a large disparity in employment rates between women and men. According to Eurostat, in 2018 the employment rate in the $28 \mathrm{EU}$ states was $67 \%$ for women and $79 \%$ for men (persons aged 20-64) [21]. Differences have also been observed in the gender employment structure. In 2018, in the European Union states (EU-28), 36.5\% of working women and $8.3 \%$ of working men (people aged 15-64) were employed part-time [21]. Not unlike the employment rate, the differences between men and women in each EU country were significant, and the percentage of women working part-time was always higher than that of men [21]. One can also see significant differences in part-time employment across different parts of Europe. Poland belongs to the group of countries with part-time employment is below $10 \%$, with an average of $6.4 \%$ (9.7\% among employed women and $3.8 \%$ among employed men). A similar level of part-time employment can be observed in most countries of Central and Eastern Europe as opposed to trends in Western Europe, where this form of employment concerns more than $20 \%$ of employees (in the Netherlands it reaches 50\%). A common element, however, for the whole of Europe is definitely a higher share of women in part-time employment, on average three times higher than for men [21].

The lower female employment rate is to a great extent attributable to the greater involvement of women in unpaid housework and the need to look after other family members. The allocation of responsibilities within a family is still largely gender-dependent $[22,23]$. For example, in families with small children fathers spend on average more time outside home, while mothers spend more time on childcare duties [24], and they are also more likely to escort their children to nurseries/kindergartens/schools [20,25]. Eurostat statistics confirm that childcare or care for disabled adults along with other family, nurturing and personal responsibilities account for 32\% cases of women aged 20-64 not undertaking work as compared to $5 \%$ cases of men of the same age [21]. The traditional division of roles within a family is also one of the reasons why people decide to work part-time [26]. The number of women in the EU who work part-time due to responsibilities related to childcare or care for disabled adults and to other family and personal tasks is much higher than that of men- $42 \%$ of women compared to $16 \%$ of men (working persons aged 15-64) [21].

Moreover, the EU still has a high percentage of women who work in lower-paid industries (e.g., lodgings, catering, education, healthcare, social care); at the same time, women are under-represented in top management [20]. In the case of women, being a parent is a factor that reduces the employment rate. Women do unpaid housework or work part-time to be able to reconcile professional duties and care tasks. This has a negative effect on their career and gives rise to discrepancies between the average earnings of men and women [23]. According to Eurostat, in 2017 in the $28 \mathrm{EU}$ states, the unadjusted gender pay gap (difference between average gross hourly earnings of male and female employees as percentage of male gross earnings) was equal to $16.0 \%$ [21].

European and American studies on gender differences in travel suggest the following implications of the socio-economic situation of women (see Table 1):

1. In relation to the trip purpose, hours of travelling, number of trips and distance travelled the differences in travel behaviours between the two genders are connected to the participation in the labour market and the roles assumed by men and women in the family [27-31]. 
2. Moreover, in relation to the trip purpose: the difference is not static but depends on the specific life situation and on changes associated with the respective phases of human life [32]. The key stages which have an impact on travel behaviours include starting work, having children and retiring $[20,32,33]$.

3. In relation to transport mode choices: the pay gap decreases a woman's potential to use more expensive, higher-quality transport services and a private car [34-36].

4. In relation to car usage and travel distances: the gradual increase of women's share in the labour market and their growing involvement in jobs contrasting with the traditional housewives' roles led to a dramatic change in women's travel behavioursthis especially manifests itself in the growing distances travelled by women and the increasing use of private cars [37-39].

Table 1. Socio-economic factors affecting women's and men's travel behaviours.

\begin{tabular}{|c|c|c|c|c|c|}
\hline & \multicolumn{5}{|c|}{ Travel Behaviour Indicating Gender Differences } \\
\hline & Trip Purpose & Hours of Travelling & $\begin{array}{c}\text { Number of } \\
\text { Trips/Travel Chain }\end{array}$ & Distance Travelled & $\begin{array}{l}\text { Car Usage/Transport } \\
\text { Mode Choice }\end{array}$ \\
\hline Significant difference & $\begin{array}{l}\text { women travel more } \\
\text { often for shopping, as } \\
\text { companions of other } \\
\text { people, and to handle } \\
\text { household-related } \\
\text { administrative matters; } \\
\text { their trips are not as } \\
\text { linear as for men }\end{array}$ & $\begin{array}{l}\text { women travel more } \\
\text { often outside rush hours }\end{array}$ & $\begin{array}{l}\text { women make more trips } \\
\text { per day and within } \\
\text { complex travel chains }\end{array}$ & $\begin{array}{l}\text { lower for woman, and } \\
\text { growing together with } \\
\text { higher involvement } \\
\text { in jobs }\end{array}$ & $\begin{array}{l}\text { women more often } \\
\text { travel as a passenger in } \\
\text { a private car, more often } \\
\text { use public transport, } \\
\text { more often walk }\end{array}$ \\
\hline \multicolumn{6}{|l|}{$\begin{array}{l}\text { the socio-economic } \\
\text { factor influencing } \\
\text { women's } \\
\text { travel behaviour }\end{array}$} \\
\hline $\begin{array}{l}\text { family roles (e.g., care } \\
\text { responsibilities, other } \\
\text { unpaid housework) }\end{array}$ & yes & yes & yes & yes & \\
\hline $\begin{array}{l}\text { structure of } \\
\text { employment (part-time) }\end{array}$ & yes & yes & yes & yes & \\
\hline $\begin{array}{l}\text { life stage (age, starting } \\
\text { work, having } \\
\text { children, retiring) }\end{array}$ & yes & & yes & & yes \\
\hline pay gap (low wages) & & & & & yes \\
\hline
\end{tabular}

Source: own elaboration based on [20,31,37-52].

As far as the trip purpose is concerned, men usually travel for work or business matters, while women usually travel for shopping, as companions of other people, including children commuting to school, and to handle household-related administrative matters [31,40-42]. The discrepancies have been confirmed by, inter alia, travel surveys conducted in Spain [43], according to which 12\% of women travel for work (as compared to $21 \%$ of men), $10 \%$ of women travel for shopping, $6 \%$ of women accompany other persons/children in their travel, with the corresponding proportion for men being $4 \%$ and 3\%, respectively. A travel survey conducted in the UK in 2017 [44] (Department of Transport, 2018) has also confirmed these observations. The study revealed that the largest gender gap between men and women with respect to trip purposes concerns work (13\% women vs. $17 \%$ men) and escort for education/other escort (16\% women vs. $13 \%$ men). In the 21-59 age group, i.e., people in employment, with family/care responsibilities, the gap is even wider-in the case of the "work" trip purpose, the difference is 9 percentage points, while for the "escort education/other escort", the difference amounts to 7 percentage points.

The division of roles within the family and the differences in trip purposes between the genders affect other aspects of travel behaviour. Trips undertaken by women in contexts unrelated to work are often much more scattered in terms of origins and destinations (a woman needs to get to a shop, kindergarten, visit public offices for administrative matters) and are frequently made outside rush hours [20-50]. The need to look after their families and other persons manifests itself also in the greater number of trips undertaken by women [52,53], often characterised by complex travel chains: woman who travels 
from/to work drops off/picks up her child from a kindergarten, does shopping and errands $[39,45,47,50]$. The composition of the trip chain especially shows differences for married adult women with young children, who tend to have more complex nonwork trip chains, but simpler work trip chains than their male counterparts, which is caused by the fact that women have more complex and intricate scheduling activities. However, this gender difference disappears with age [39]. Meanwhile, men engage in much more linear travel patterns-they travel mostly to/from work, usually without stopping in as many places as women do [49,52]. For example, British travel studies conducted in 2017 revealed that on average women make 1000 trips per year, while men make 948 trips [44]. The analyses of travel behaviour of the Andalusian population showed that women demonstrate greater mobility, making 3.69 trips per day, with men making 3.52 trips per day [52]. This increased mobility was especially visible among women aged 30-39, being in a certain stage of life (adult with young children). In the studies [48], the differences were more noticeable for people in employment-working women were making 110 trips more per year than men of the same status. The greatest discrepancies were noticed in households with small children, where women were making 5.2 trips per day while men were making 4.7 trips. In another study [49], greater female mobility was noted in the case of women working part-time.

As concerns the mode of transport, women in general demonstrate more sustainable travel behaviours than men, relying more often on public transport or travelling on foot $[46,51,52]$. At the same time, private cars, motorcycles and bicycles are more often utilised by men $[31,39,49,54]$. Moreover, when women do use a car, they travel as passengers much more often than men [20]. This is confirmed by surveys conducted in 27 EU states [55], which show that individual motorized transportation is used by $47 \%$ of women and $61 \%$ of men, while public transport is used by $23 \%$ of women and $18 \%$ of men. Walking, on the other hand, is chosen by $19 \%$ of women and $10 \%$ of men. According to this study almost the same percentage women and men uses cycling ( $9 \%$ women and $8 \%$ men). In turn, a travel survey conducted in Spain [43] revealed that private cars and motorcycles are used by $39.0 \%$ of women and $60.7 \%$ of men, public transport by $21 \%$ of women and $9 \%$ men, and bikes and walking together by $37 \%$ of women and $25 \%$ of men. The discrepancies in the use of cars have also been confirmed by the results of studies presented in a report entitled "Attitudes of Europeans towards urban mobility" [56], according to which $42 \%$ of female respondents and $57 \%$ of male respondents said they use a car (as a driver or passenger) at least once a day, with $14 \%$ of women and $10 \%$ of men claiming that they never use this mode of transport. A study conducted in the United Kingdom showed that $37 \%$ of women and $44 \%$ of men use cars as drivers and $24 \%$ of women and $17 \%$ of men rely on them as passengers [44]. Interestingly, men are found to use cars as an "investment in identity" (reinforcing the predominant version of masculinity), while women's use of cars is seen mostly in terms of functionality - as a means of moving from place to place [7,57]. For women, a car seems to be a sort of an "extension of home", allowing them to do shopping more effectively and escort children to school. The differences in the selection of a means of transport are determined by social and economic factors [58], which in the case of women translate into more limited access to a private car and possibilities for its use [22]. Moreover, women in general are more eco-friendly, including in the context of mobility $[19,20,59]$. Women also often feel reluctance and fear towards certain means of transport and services, such as autonomous vehicles [60].

Another factor which makes a difference, when it comes to travel behaviours of women and men, is the travel distance $[38,50,51,61,62]$. A recent mobility study conducted in Germany [63] revealed that men travel greater distances. According to the survey, women travel on average $33 \mathrm{~km}$ per day, while the corresponding number for men is $46 \mathrm{~km}$ per day. The greatest discrepancies are observed in the case of women and men aged 30-59. Results of the Swedish National Travel Survey 2015-2016 [64] show that in Sweden women travel $36 \mathrm{~km}$ per day (including $22 \mathrm{~km}$ by car) while for men it is $40 \mathrm{~km}(27 \mathrm{~km}$ by car). In the UK, men travel 11,368 km per year, while women travel $9833 \mathrm{~km}$ [44]. The 
differences are especially visible in the case of travelling to and from work-men commute more and travel more on work-related business [22]. For women, on the other hand, the area of access to jobs is often smaller due to time constraints and more limited access to a private car [29]. European statistics on commuting patterns at regional level [21] show also that in 2015 the share of male and female outbound commuters among all employed persons was systematically higher for men in each of the $20 \mathrm{EU}$ Member States for which data are available. The biggest gender gaps were recorded in those EU Member States that had the highest shares of outbound commuters (Belgium, United Kingdom), where the proportion of men commuting to a different region was 6.0 percentage points higher than the corresponding share for women. Men tend to occupy more management roles, which ensures high income, hence such employees are willing to travel for further distances which may explain, why commuters tend to be predominantly male [21].

The above studies were carried out mainly in Western Europe and the United States on a national or regional scale. In Poland and other countries of Eastern and Central Europe, it is difficult to find any publications showing gender differences in travel behaviour. In addition, in Poland there are no periodical studies of travel behaviour of the population on a national scale. Gender travel behaviour patterns can only be analysed on the base of CTS conducted in larger cities, or of smaller-scale studies accompanying specific transportation projects. It is also difficult in Poland to obtain detailed data on specific socio-economic characteristics (e.g., the level of income differentiated by gender and within territory), hence it is even more difficult to provide multivariable analyses considering the most key variables affecting travel behaviour.

\section{Methods}

The analyses conducted in this paper are intended to provide answers to the following research questions: (1) do the historical, cultural and social factors which have shaped the family roles and women's situation in the Polish labour market explain women's travel behaviour, (2) are there differences in the travel behaviours of women and men within Poland, (3) are these differences the same as in other European countries, (4) is there awareness of women's mobility needs in Poland, and (5) are Polish transport systems adapted to women's needs? Bearing in mind the research questions posed, the answers were sought using several research methods (Table 2).

Table 2. Research methods used in the research.

\begin{tabular}{|c|c|c|c|c|}
\hline No & Method & Purpose & $\begin{array}{l}\text { Research } \\
\text { Question }\end{array}$ & Source of Data \\
\hline 1 & Review of data & to explain the situation of women in Polish labour market & 1 & $\begin{array}{l}\text { Studies presenting historical, cultural and } \\
\text { social factors determining the role of a } \\
\text { woman in society }\end{array}$ \\
\hline 2 & Review of data & $\begin{array}{l}\text { to indicate factors related to Polish labour market that may explain } \\
\text { travel behaviours }\end{array}$ & 1 & GUS base and documents \\
\hline 3 & Analysis of data & $\begin{array}{l}\text { to measure aspects of travel behaviours } \\
\text { to diagnose gender differences in travel } \\
\text { to conclude about differences and similarities on Polish and } \\
\text { European women's and men's travel behaviour }\end{array}$ & 2,3 & CTS for selected Polish cities \\
\hline 4 & $\begin{array}{l}\text { Review and analysis } \\
\text { of data }\end{array}$ & $\begin{array}{l}\text { to examine the level of decision-makers' and planners' awareness } \\
\text { of gender differences in travel and women's mobility needs }\end{array}$ & 4 & Policies and plans for selected Polish cities \\
\hline 5 & Review of data & $\begin{array}{l}\text { to examine transportation access and adaptation of transport } \\
\text { systems to women's needs }\end{array}$ & 5 & Research reports and social initiatives \\
\hline
\end{tabular}

Source: own elaboration.

First, the studies on historical, cultural, and social factors determining the role of a woman in society were reviewed to explain the situation of women in the Polish labour market. This provided the context for further considering factors related to the Polish labour market that may explain travel behaviours.

Next, data from the base and documents of the Statistics Poland (Główny Urzad Statystyczny (GUS)) related to Polish labour market were reviewed to indicate factors that may explain women's and men's travel behaviours. These factors are related to an employment rate, percentage of women and men working part-time, reasons for undertaking this 
kind of work or professional inactivity, and average gender pay gap in Poland. The GUS data were derived most and foremost from the Polish Labour Force Survey covering people aged 15 and above, from unemployment registers kept by Job Centres, working conditions surveys as well as studies of pay by profession and a modular study "Reconciliation between work and family life in 2018" conducted in 2018. Moreover, the authors of this article took into consideration the results of the "Report on the situation of parents on the labour market", one of the elements of the "PI-Innovative model—reconciliation of professional and family life by women" project, executed as part of the Operational Programme Human Capital 2007-2013 [65]. The data presented in the Report were mostly derived from statistics published by the Polish Statistics and the Social Insurance Institution.

Data sourced from the CTS were analysed to measure aspects of travel behaviour and diagnose any gender differences in travel in Polish cities. As research presented in this paper has comparative nature (travel behaviours in Poland vs. in other European countries), results of the CTS analysis were also used to conclude about differences and similarities on travel behaviour of Polish and European women and men.

The CTS are a set of multifaceted studies, measurements and analyses of travel and mobility undertaken to attain specific goals in a given area, using methods adapted to research objectives, local conditions, organisational and financial capacities. The CTS are designed to provide comprehensive and current information on travel patterns and mobility in a city and its surrounding areas, and the results of the studies are used for decision-making in the organisation and planning of transport system development. Due to their high cost and long duration, surveys of this kind are carried out in Poland once every 7-10 years, covering mainly bigger cities (more than one hundred thousand inhabitants).

A crucial part of the CTS are questionnaires (surveys) conducted with the participation of members of randomly selected households, providing information on, inter alia, travel behaviours and preferences. The research is based on a travel log in which information on all travels made by respondents on the day preceding the research is recorded (origin, destination, trip purpose, mode of transport used, time of starting and finishing the trip). Interviews are conducted on Wednesdays, Thursdays and Fridays, with the study usually being administered to household members above six years old. The structure of the studied group is controlled in terms of territory, gender and age. The city is divided into transportation zones and household addresses are drawn randomly for each zone, with the number of households in the zone being proportional to the size of the population living there. Due to climate considerations and summer holidays, the CTS are usually conducted in Poland between April and June or October and November. Source data (travel logs) were obtained for seven cities: Warsaw, Cracow, Wrocław, Gdańsk and Szczecin, all of which are the largest Polish cities, both in terms of population and area, as well as for two slightly smaller urban areas-Kielce and Rzeszów. Table 3 below presents information on the year in which the latest CTS studies were conducted in a city and the number of respondents-household members. Based on the results of foreign publication reviews, differences in gender travel behaviours were studied, including the trip purpose, number of trips and the modes of transport used. The differences in travel distances were left out from the analysis, since this aspect is very rarely indicated in the CTS surveys conducted in Polish cities.

Table 3. Basic information concerning the comprehensive travel studies in the analysed cities.

\begin{tabular}{cccc}
\hline City & Population & Year CTS Was Conducted & Number of Respondents \\
\hline Warsaw & $1,764,615$ & 2015 & 17,000 \\
Cracow & 767,348 & 2013 & 13,192 \\
Wrocław & 638,586 & 2018 & 7450 \\
Gdańsk & 464,254 & 2016 & 10,115 \\
Szczecin & 403,883 & 2016 & 5789 \\
Kielce & 195,774 & 2015 & 4668 \\
Rzeszów & 189,662 & 2016 & 6349 \\
\hline
\end{tabular}


Next, policies and plans concerning directions of actions, mandatory standards and guidelines or recommendations for spatial and transport planning process in Poland were reviewed and analysed. The goal of the review and analysis was to examine the level of decision-makers' and planners' awareness of gender differences in travel and women's mobility needs. The documents were collected only for cities presented in Table 3 (Warsaw, Cracow, Wrocław, Gdańsk, Szczecin, Kielce and Rzeszów). The analysis concerned only the documents currently in force.

The review of data was also applied to examine adaptations of transport systems in Polish cities to women's needs. In this case the source of data included research reports on transportation access and travel conditions by selected means of transport. Information on social initiatives focusing on women's travel needs was reviewed as well. The reports and information on social initiatives were collected also only for cities presented in Table 3.

\section{Historical, Cultural and Social Factors}

The perception of female roles and the position of a woman in the society has changed significantly over the centuries in Europe, including in Poland. In Judeo-Christian, Mediaeval Europe (V-XV century), women were treated as the property of men and the latter were obliged to support them financially. In the Germanic part of Europe, the image and perception of mediaeval women was different than in Slavic countries: in the Germanic societies, it was emphasized the negative aspects of femininity related to a woman's morality and personality and her lack of self-catering skills. Slavic societies (The territory of Poland has always been inhabited by a mostly Slavic population.), treated women with greater respect [71], although women and men were considered equal partners in the family, women were denied the right to education and numerous professions. The 15th and 16th centuries brought changes in both European and Polish law which started to, for example, allow widows to claim a share of their late husband's estate (to the exclusion of children) and regulated the question of dowry. In the social context, however, women were still expected mostly to keep house and raise children. Historians stress [71,72] that from the 17th century, women's role in society grew, and with the growing importance of the Church, women had more opportunities to receive education throughout Europe. Moreover, women's prominence in areas other than family life started to grow only in the 17th century. Women in Europe started socializing, participated in debates and, owing to growing rights to education, challenged stereotypes related to their intellectual inferiority [73]. The female social role also started evolving-women, in their capacity as mothers, were the first teachers of their children. The access to many privileges depended on birth status and wealth, which-considering that the law did not allow marriages between people from different social classes-made it more difficult for women to improve their position. The Age of Enlightenment (18th century) in Europe is a period of development of new ideas including the idea of gender equality. However, over the next decades, women's rights were consistently reduced by the Napoleon Code adaptation (1804), which despite its innovativeness related to closure of feudalism, reduced the woman to the role of wife, mother and housewife. The situation was also not improved by the Spring of Nations (1848) and revolutionary movements in Europe, which ignored the issue of women's emancipation. The last decades of the 19th century opened new opportunities for women in connection with the need to use them on the labour market, which greatly empowered women, allowing them to make independent life choices. In Europe, women also gained access to universities in the last decades of 19th century.

The Constitution of the Duchy of Warsaw (Duchy of Warsaw - a state existing from 1807 to 1815 on the territory of present Poland, formally independent but in reality subject to the French Empire and its monarch, the emperor Napoleon Bonaparte; a political ersatz of the Polish state.) (1807-1815) regulated to a large extent the female status within a family. The Constitution imposed on both parents the obligation to support and raise their children and obliged the husband to protect his wife and to provide her with all the necessary goods within his capacity. 19th century women in Poland were expected mainly to keep house 
and to manage finances. It was at that time that feminist movements started to develop in Poland, which postulated equality of women and men before the law and a greater impact on the upbringing and education of children. Not many feminists, however, brought up the question of marital equality [71].

It was not until the social changes triggered by the armed conflicts in the first half of the 20th century and men's serving on the front lines, that the family structure evolved everywhere in Europe. Women became much more independent and in the inter-war period started to fight for gender equality. In Poland, after WWII, the woman's situation in social life underwent a major change under Stalinism (1948-1955). In Western Europe, democratic governance and the market economy system encouraged gender equality, while in Eastern Europe Stalinism and communism actually suppressed the opportunities of women. However, despite being one of the most politically repressive periods in history, it also offered women a chance to achieve economic independence and social prestige. By gaining access to education and entering jobs traditionally perceived as predominantly male (e.g., miner, tram operator), women finally got a chance to advance socially, which had an impact on their relations with men and their position in the family, shaping the general attitudes to the existing allocation of roles within society [3,74]. Fidelis [3] stresses that women's participation in the labour market was a "double burden", i.e., they were forced both to work at paid jobs as well as to do unpaid housework. Nevertheless, women's financial independence influenced a more equal attitude to housework.

The subsequent decades of the communist regime (1956-89) drove women out of the labour market, especially out of prestigious and well-paid jobs, pushing them into more "female" positions, including those of nurses, kindergarten teachers and administration clerks. Strict laws on female labour were passed which naturally strengthened the image of the Polish woman as a wife and mother, the backbone of the family.

During the period of transformation, the Solidarity Movement (The system transformation in Poland was a sum total of all of the changes that started in 1980s, aimed at the development of a free market, creation of a civil society and democratisation. Poland was the first country in the eastern bloc to embark on the path of transformation. The founding of the Independent Self-Governing Labour Union "Solidarity" in 1980 (a Polish trade union established to protect employee rights, and until 1989 also one of the main anti-communist opposition centres), laid the foundations for Polish sovereignty.) (1989-92) maintained close ties to the Catholic Church, which for women translated into further enhancement of the "guardian of the hearth and home" role and into weakening of the emancipation movements. The liberal abortion law passed in 1956 was also amended and a new act was adopted in 1993 that allows women to terminate pregnancies in extreme circumstances only. It could be said that feminism was dubbed a relic of the evil communist system [4]. The perception of women within the context of family life and their social roles has been changing over the last 30 years, which is the result of the improving economic situation and growing independence of women. This trend is confirmed by a survey on female and male roles in the family conducted in July 1994 by the Centre for Public Opinion Research and in January 2014 by TNS Poland. The percentage of people who think that women should be mothers and wives first rather than career-makers has dropped-in 1994 this view was expressed by $50 \%$ of respondents, while twenty years later-by $31 \%$ [75]. Nevertheless, the strong, permanent influence of the Church and the Catholic religion on all aspects of social life lasting for decades is unique for Poland compared to all other European countries (According to data presented by the Pew Research Center [75] 87\% of adults in Poland identify as Catholic; in Croatia-84\%; in Italy-78\%; in Portugal-77\%; in Spain and France-60\%; in Germany-43\%; in the Netherlands and UK-19\%; in Norway, Sweden, Finland, Denmark and Estonia $<5 \%$.). This is also reflected in the traditional division of roles in households. The adherence to traditional family values depends on religious involvement and vary considerably across European countries: Ireland, Italy and Portugal are more in favour of traditional family values, but Spain, Germany and the Netherlands accept it least [76]. In Poland one can observe a strong political and social resistance to 
introduction of systemic solutions for increasing gender equality or even social dialogue on the gender issues-what is currently one of the leading topics in Western Europe.

The current political situation in Poland has brought the political discourse even closer to the religious narrative of the Church, deprecating feminist ideas [9]. This is also reflected in the marginalization of the problem of gender equality in development policies and strategies in many life areas, including gender equity on labour market or spatial and transport planning, which influences transport access for women as well as possible way to overcome the existing barriers. In present-day Poland, it is still a woman who is more responsible for keeping house and raising children. It is confirmed by research conducted by GUS in a report entitled "Reconciliation between work and family life in 2018". Out of the 22,969 respondents aged 18-64 covered by the 2018 survey, $37.3 \%$ declared that they looked after their own children under 15 years of age or other dependent family members aged 15 and above [6]. Women played the role of carers much more often (41.6\%) than men (33.1\%).

When analysing the cultural and social aspects of travel behaviour, especially in the context of the last century, we should also pay attention to the role of the private car in the perception of an individual's status and position. It is a symbol of freedom, with some vehicle brands being a wealth indicator. Historically, in the context of gender, the car as a product of the male world of engineers (despite the women's contribution to the development of the automotive industry [59], was considered a "man's thing", with the woman relegated to the passenger seat. In the 20th century, a woman behind the wheel became a symbol of emancipation. In many societies, especially in Poland, gender stereotypes of cars as masculine attributes and women as being incapable and unsafe drivers are still very much alive [7]. However, thanks to the growing wealth of society and the open possibility of importing used cars from Western Europe over the past two decades, private car ownership has ceased to be a luxury in Poland, which has resulted in an increase in the share of women with a driving license. What brought the period of Stalinism and communism together with the role of the Church in the transformation and significance of the Catholic religion in Poland, is constantly strengthening the dual role of women in society - the need to take up professional work and at the same time fulfil the duties of Polish Mother (A common and still popular myth, according to which Polish Mother is a woman, who devoted her whole life to the family and raising children in the spirit of traditional and patriotic values.), as well as deny the participation of women in the most profitable economy sectors. Historical burdens and the current political situation can also be seen as barriers to achieving equal access to transport, and moreover-cause other types of barriers (e.g., related to social roles, economic situation or infrastructure) to go unnoticed or become marginalized.

The socioeconomic situation of women is reflected in labour market statistics presented in the next chapter and later on in different travel behaviours: travel purpose, choice of transport mode and number of trips, as well as preferences related to the quality of the transport system.

\section{Situation of Women on The Polish Labour Market}

GUS data concerning women's share in the overall number of people in employment, show a gradual but systematic increase in women's employment rates on the Polish labour market. In 1950, the share stood at around 31\%, in the early 1970 s it exceeded $40 \%$, and since 2014 it has been at a level of nearly 49\% [77]. Despite this consistent increase of women's involvement on the labour market, there is still a significant disparity between female and male employment rates. An analysis of data from the past few years (Table 4) reveals that between 2011 and 2017, the gender employment rates gap remained at a similar level: around 15 percentage points for women and men in general and around 8-9 percentage points for working-age population, with 8.9 percentage points in 2017. Discrepancies can also be seen in the employment structure of women and men. In Poland, women's involvement in part-time work activities is twice as high as that of men—in 2017 
the percentage of women employed part-time was $10.6 \%$, while for men the corresponding figure was $4.4 \%$ [77].

Table 4. Gender employment rates in Poland, people aged 15 and above, 2011-2017.

\begin{tabular}{ccccc}
\hline \multirow{2}{*}{ Years } & \multicolumn{2}{c}{ Total Number of People } & \multicolumn{2}{c}{ Working-Age Population } \\
\cline { 2 - 5 } & Women & Men & Women & Men \\
\cline { 2 - 5 } & \multicolumn{2}{c}{$[\%]$} \\
2009 & 43.3 & 58.3 & 60.2 & 69.6 \\
2011 & 43.4 & 58.9 & 60.6 & 70.1 \\
2013 & 43.4 & 58.5 & 62.2 & 70.4 \\
2015 & 45.2 & 60.6 & 65.1 & 73.4 \\
2017 & 45.8 & 62.2 & 67.7 & \\
\hline Source: [77-79]. & & & &
\end{tabular}

One of the reasons for the lower employment rates in the case of women are the already-mentioned historical factors related to women's gradual access to the labour market [77]. It also has to do with the greater involvement of women in unpaid housework and care for other family members [21]. As has already been pointed out, the allocation of responsibilities in the family in Poland is still largely gender dependent.

The data published by GUS also confirm that family responsibilities are one of the main causes of the differences in the rates of female and male professional inactivity. Women, much more often than men, work outside the traditional understanding of labour market because of this type of duty [77]. Family responsibilities are the second, after retirement, most frequent cause of female professional inactivity and the top one in the case of women aged $25-34,35-44$ and $45-54$, where the inactivity rates amount to, respectively, $79 \%, 76 \%$ and $53 \%$.

In Poland, the traditional division of roles within a family is also one of the reasons why people decide to work part-time. The necessity to provide care to children and other persons, as well as other personal and family circumstances, are the second most important reason in the case of women (16.5\%), very uncommon for men (only $4.5 \%$ of men) [77]. Women's current professional status is, to a much greater extent than that of men, affected by duties related to looking after children below 15 years of age-this is confirmed by $26 \%$ of women, as compared to only $9 \%$ of men [77]. Most often women who want to take care of their children are forced to reduce their working hours and to use maternity/carer's leave. In Poland, career breaks for childcare reasons are almost always taken by women-men very rarely rely on this type of solution. Most frequently, such breaks range from half a year to two years. Poland is one of the EU countries with the longest maternity leave [23].

Some women always work outside the traditional understanding of labour market, doing unpaid housework instead. Others do not go back to work after maternity/carer's leave, afraid that they will not be able to reconcile the family and professional spheres [65]. Fixed-term employment contracts are another reason why women do not return to workemployers do not want to prolong contracts with women who are mothers, considering them much less flexible that their childless peers [65]. Some women work part-time or based on other types of contracts to be able to reconcile work with care tasks. Not unlike other EU states, Poland still has a high rate of women who work in lower-paid industries (e.g., lodgings, catering, education, healthcare, social care, other services) and female employees are less likely to be offered top managerial positions [77]. All of these factors have a negative impact on the development of women's careers and the amount of their earnings.

According to the Eurostat data for 2017 [21], Poland is one of the EU states with a lower unadjusted Gender Pay Gap (7.2\% vs. 16.0\% for UE-28). When analysing the gender pay gap in Poland, we could also rely on data compiled by GUS in the years 2006-2016 which show that women's mean gross hourly earnings amounted to $86.5-91.7 \%$ of the mean gross hourly earnings of men [68]. In October 2016, the mean gross hourly earnings 
of men were higher than the mean gross hourly earnings of women by $12.1 \%$, while the mean gross monthly earnings were $18.5 \%$ higher [80]. Significantly, men earn more than their female colleagues with the same qualifications and work experience.

When analysing travel behaviour it is important to have in mind factors described above, since studies by Uteng and Cresswell [34], Basarić et al. [35] and Mejia-Dorantes [36] prove the pay gap and women's lower earnings decrease their potential to use more expensive, higher-quality transport services and a private car, and therefore foster the use of public transport and walking, which also confirms that the socioeconomic situation of women is one of the barriers to transportation access for women.

\section{Gender Travel Behaviours}

The results of studies conducted abroad prove gender differences in travel. Taking into account these results, CTS for selected Polish cities were analysed to examine gender travel behaviours in Polish conditions to see if there are differences in the trip purpose, number of trips and modes of transport and if these differences can be attributed to the roles allocated to women and their participation in the labour market. The difference in travel distance was not studied, since Polish CTS focus on the travelling distance on very rare occasions, so it would be hard to verify this claim.

\subsection{Trip Purpose}

Results of the CTS surveys conducted in Polish cities confirm the result of foreign studies. Differences in gender trip purposes are visible especially in the case of travelling for work, shopping, services and in administrative matters. They are present in each of the cases shown in Table 5. The most conspicuous differences in work-related trips can be seen in Gdańsk (six percentage points) and in Warsaw and Rzeszów (around five percentage points), while in shopping- and administrative matter-related trips-in Gdańsk (seven percentage points), Cracow and Rzeszów (six percentage points) and in Szczecin (5.4 percentage points). In Kielce [17] and in Wrocław [13], where the CTS addressed the trip purpose in a general manner, it is noticed that more men than women travel between home and work and work and home (in both cities the difference in trip purpose amounts to six percentage points). Moreover, in these two cities, the number of trips between home and other places and other places and home in the case of women is six percentage points higher than in the case of men. These trips are also made for the purpose of handling administrative matters and shopping.

Table 5. Differences in gender trip purposes in selected Polish cities.

\begin{tabular}{|c|c|c|c|c|c|c|c|c|c|c|}
\hline \multirow{3}{*}{ Trip Purpose } & \multicolumn{2}{|c|}{ Cracow * } & \multicolumn{2}{|c|}{ Gdańsk ** } & \multicolumn{2}{|c|}{ Warsaw * } & \multicolumn{2}{|c|}{ Rzeszów * } & \multicolumn{2}{|c|}{ Szczecin ** } \\
\hline & $\mathbf{W}$ & $\mathbf{M}$ & $\mathbf{W}$ & $\mathbf{M}$ & $\mathbf{W}$ & $\mathbf{M}$ & $\mathbf{W}$ & $\mathbf{M}$ & $\mathbf{W}$ & $\mathbf{M}$ \\
\hline & \multicolumn{10}{|c|}{$[\%]$} \\
\hline Home & 46 & 47 & 46 & 47 & 45 & 45.6 & 49.8 & 49.7 & 42.2 & 43.9 \\
\hline Work & 18 & 22 & 17 & 23 & 23 & 27.9 & 15.5 & 20.7 & 20 & 24 \\
\hline Primary school, junior secondary and secondary school & & & 5 & 7 & 3.3 & 4.6 & \multirow{2}{*}{7.4} & \multirow{2}{*}{8} & 5.2 & 6.6 \\
\hline University & 9 & 10 & 2 & 2 & 2.2 & 2 & & & 1.8 & 1.8 \\
\hline $\begin{array}{l}\text { Shopping and services (except for shopping } \\
\text { malls), public offices }\end{array}$ & 17 & 11 & 16 & 9 & \multirow[t]{2}{*}{11.8} & \multirow[t]{2}{*}{8} & 17.3 & 11.4 & 16.8 & 11.4 \\
\hline Entertainment, leisure, visits & 6 & 5 & 6 & 7 & & & 3.8 & 3.7 & 2.8 & 3.5 \\
\hline Handling work-related matters during work hours & 1 & 2 & 0 & 1 & no data & no data & 0.2 & 0.9 & 0.7 & 1.3 \\
\hline $\begin{array}{l}\text { Escorting children to school, kindergarten } \\
\text { Escorting people to work, modes of transport, other places }\end{array}$ & 2 & 2 & $\begin{array}{l}4 \\
1\end{array}$ & $\begin{array}{l}2 \\
2\end{array}$ & \multirow{2}{*}{14.7} & \multirow{2}{*}{11.9} & 0.9 & 0.9 & 4.9 & 3.1 \\
\hline Other & 1 & 1 & 2 & 1 & & & 5.1 & 4.7 & 5.6 & 4.4 \\
\hline
\end{tabular}

* trip destination purpose; ${ }^{* *}$ trip origin and destination purpose; W—women, M-men. Source: Authors' study based on: [66-70].

A slightly higher percentage of trips related to handling of work-related matters during work hours is conducted by men (a difference of 0.6 to 1 percentage point). Moreover, only in the case of Gdańsk, i.e., one of the seven analysed cities, did the researchers distinguish 
the trip purpose of escorting children to school/kindergarten where women usually make slightly more trips than men.

A review of the literature suggests that the trip purposes are not static but evolve over the course of human life, with such key phases as starting work, having children and retiring $[20,32,33]$. The evolution of trip purposes depending on the different life stages of both women and men can also be observed in Poland, for example by analysing the results of the CTS conducted in Cracow, as shown in Figure 1. People of school age and university students, regardless of gender, travel practically for the same purpose, mainly to the places where they receive education (higher education considered, in Poland this stage may last up to 24 years). Following the completion of education and starting a job, trips are made to the workplace. In households without children, travel behaviours of working men and women are very similar, although still more women travel for shopping or to handle administrative matters. The situation changes for women when they have their first child (the average age of a woman giving birth for the first time is 26.7 years in Poland, while the average age of women at first delivery-29 years [21]. At this point, women tend to take on most of childcare responsibilities and housework, and if they keep working professionally, it is usually on a part-time basis. This gender-specific distribution of roles increases the rates of travelling for shopping, to public offices and with the purpose of accompanying other people, while men travel mostly for work. Further changes in travel behaviours appear when people reach retirement age (60 years for women and 65 for men) when both genders stop travelling for work and start travelling to shops, offices and to meet their friends.

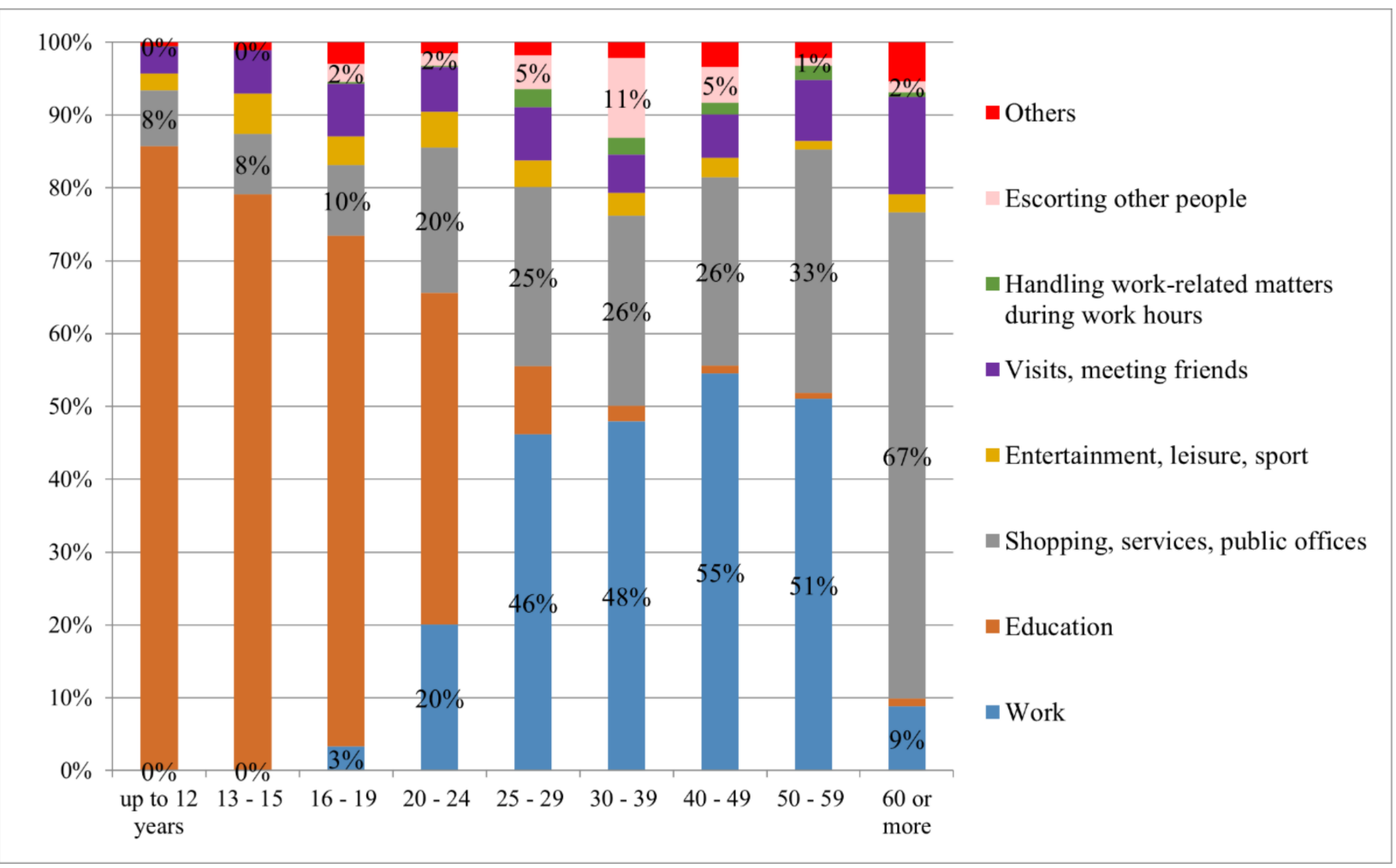

Figure 1. Trip destination purpose for women depending on the age; Cracow 2013. Author's study based on: [67].

When analysing the results presented in Figures 1 and 2 in more detail by age group, one can see that the greatest differences in trip purposes for men and women are for the ages $25-49$. Slightly more than $60 \%$ of men's purposes are related to work, while for women it is on average $50 \%$. A quarter of a women's purposes concern shopping, services, and public offices, while for men it is only about $15 \%$. For the age group $30-39$, there is a particularly visible difference in escorting other people-11\% of trip purposes for women, 
and $6 \%$ for men. The smallest differences in purposes are found for the age groups up to 19 years, with domination by education. The highest number of work-related purposes is for men aged 25-49 and for women aged 40-59. The largest share of shopping, visits and meetings is observed in retirement age.

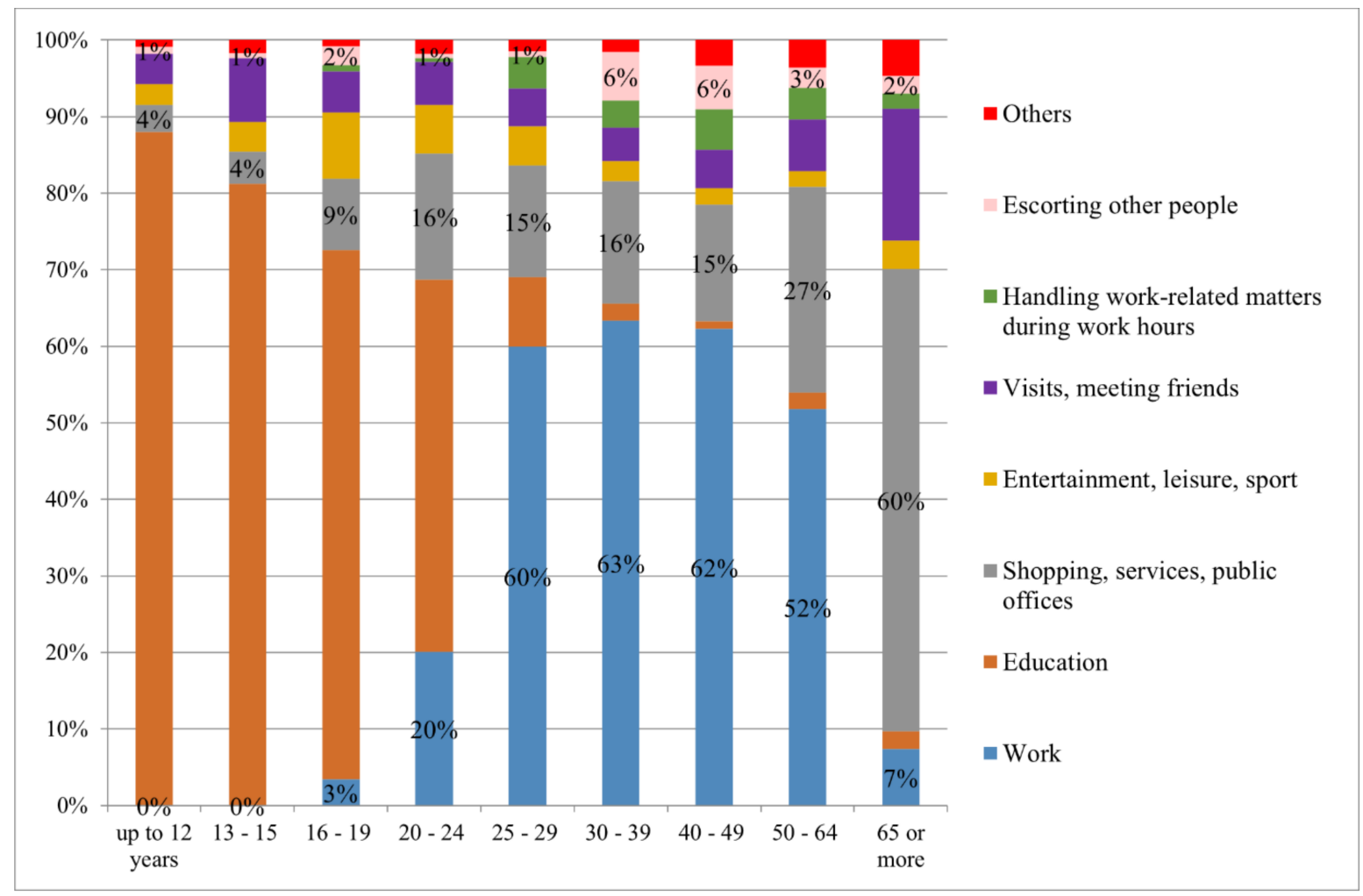

Figure 2. Trip destination purpose for men depending on the age; Cracow 2013. Author's study based on: [67].

\subsection{Number of Trips}

As concerns the number of trips, the CTS studies have inquired about the average number of trips per person per day. People who do not travel were also taken into account when calculating the average number of trips. This group comprises mostly the eldest members of society. As far as the main occupation is concerned, pensioners, people receiving disability benefits and persons classified as "Others" (mainly the unemployed and not working) refrain from travelling.

As regards the number of trips in the individual cities (Table 6), the CTS study revealed that, except for Szczecin and Kielce, there are no differences in the mobility of women and men in general. However, taking into account the fact that in the case of women aged 25-59, there is an increased rate of trips made to shops, offices or with the purpose of accompanying other people, a more in-depth analysis was undertaken to study this age group in Warsaw and Gdańsk. The analyses show that in the age group 25-59, the differences may be significant if the main occupation of the population is taken into account (Table 7). In both cities, male students are more mobile than female students. Moreover, a greater number of trips compared to men, are made by women going out to work, working at home, pensioners/women in receipt of disability benefits and, in the case of Gdańsk, unemployed women and women with another status. 
Table 6. Average number of trips made by women and men in selected Polish cities.

\begin{tabular}{ccccccc}
\hline & Cracow & Gdańsk & Wrocław & Szczecin & Warsaw & Kielce \\
\cline { 2 - 6 } & \multicolumn{5}{c}{ [Number of Trips Per Day] } \\
\hline Women & 1.89 & 2.11 & 1.70 & 1.96 & 2.00 & 2.22 \\
Men & 1.87 & 2.08 & 1.69 & 1.83 & 1.96 & 2.00 \\
Difference & 0.02 & 0.03 & 0.01 & 0.13 & 0.04 & 0.22 \\
\hline Source: $[13,17,66-70]$ & &
\end{tabular}

Table 7. Average number of trips made by women and men aged $25-59$ by main occupation; Warsaw and Gdańsk.

\begin{tabular}{|c|c|c|c|c|c|c|}
\hline \multirow{3}{*}{ Status } & \multicolumn{3}{|c|}{ Warsaw } & \multicolumn{3}{|c|}{ Gdańsk } \\
\hline & Women & Men & Difference & Women & Men & Difference \\
\hline & \multicolumn{6}{|c|}{ [Number of Trips Per Day] } \\
\hline Students & 2.14 & 2.21 & -0.07 & 1.75 & 2.16 & -0.41 \\
\hline People going out to work & 2.35 & 2.22 & 0.13 & 2.39 & 2.23 & 0.16 \\
\hline People working at home & 1.92 & 1.64 & 0.29 & 2.22 & 2.03 & 0.19 \\
\hline $\begin{array}{l}\text { Pensioners/people in receipt } \\
\text { of disability pensions }\end{array}$ & 1.48 & 1.31 & 0.18 & 1.87 & 1.40 & 0.48 \\
\hline $\begin{array}{c}\text { Unemployed } \\
\text { Others }\end{array}$ & 1.49 & 1.53 & -0.04 & $\begin{array}{l}1.98 \\
2.33\end{array}$ & $\begin{array}{l}1.62 \\
1.78\end{array}$ & $\begin{array}{l}0.36 \\
0.55\end{array}$ \\
\hline
\end{tabular}

Source: Authors' study based on: [66,68].

Although the available CTS results for Polish cities do not show that in general women travel more often than men, as do foreign studies, they prove that at the age of 25-59 differences occur and are related to the main occupation of the population. The results for working people are similar to those obtained in the studies by McGuckin and Nakamoto [48] and Hurez and Richer [49]. The results for the remaining groups showing differences are new in the context of the available foreign research and may constitute directions for future research.

\subsection{Modes of Transport Used for Travelling}

Ministry of Sport and Tourism-commissioned research on the factors affecting physical activity associated with transport use in Poland (Research conducted in 2015 on a sample of 1500 respondents, designed to obtain information on the factors influencing the choice of bike in travels to places of work and education.) reveals that in the group of working and studying people, men often travel by car and by bike, while women are more often found to travel by public transport or on foot [81]. Results of surveys conducted in Cracow, Wrocław, Warsaw, Rzeszów and Szczecin (Table 8) confirm that these trends are true for the general population of these cities. Noticeably, in the analysed cities more men than women use private cars (16 percentage points more on average) or bike (1.5 percentage points more on average). Women, on the other hand, rely much more often on public transport (10 percentage points more on average) and walking ( 7.5 percentage points more on average).

Considering that women use private cars more often as passengers, it is worth noting that in Warsaw women drive their cars in $24 \%$ of the cases of their non-walking journeys while the corresponding number for men is $43 \%$ (in Rzeszów $37 \%$ and $60 \%$, respectively). Women use cars as passengers in $8 \%$ of their non-walking journeys, while men-in $5 \%$ of their non-walking journeys (in Rzeszów 22\% and 11\%, respectively) [66,70]. 
Table 8. Modal split by gender in selected Polish cities.

\begin{tabular}{|c|c|c|c|c|c|c|c|c|c|c|}
\hline \multirow{3}{*}{ Mode of Transport } & \multicolumn{2}{|c|}{ Cracow } & \multicolumn{2}{|c|}{ Wrocław } & \multicolumn{2}{|c|}{ Warsaw } & \multicolumn{2}{|c|}{ Rzeszów } & \multicolumn{2}{|c|}{ Szczecin } \\
\hline & $\mathbf{W}$ & $\mathbf{M}$ & $\mathbf{W}$ & $\mathbf{M}$ & $\mathbf{W}$ & $\mathbf{M}$ & $\mathbf{W}$ & $\mathbf{M}$ & $\mathbf{W}$ & $\mathbf{M}$ \\
\hline & \multicolumn{10}{|c|}{$[\%]$} \\
\hline Private car & 26.2 & 43.2 & 31.5 & 50.4 & 24.9 & 40.0 & 45.5 & 59.7 & 37.1 & 50.8 \\
\hline Public transport & 41.0 & 32.1 & 32.7 & 22.8 & 52.3 & 40.0 & 28.6 & 19.8 & 39.6 & 29.6 \\
\hline Walking & 31.6 & 22.6 & 29.5 & 18.7 & 20.0 & 15.2 & 23.8 & 16.1 & 21.6 & 16.4 \\
\hline Bicycle & 0.9 & 1.5 & 5.7 & 7.6 & 2.3 & 4.0 & 2.0 & 4.2 & 0.9 & 1.9 \\
\hline Other & 0.3 & 1.6 & 0.5 & 0.6 & 0.4 & 0.7 & 0.1 & 0.2 & 0.8 & 1.3 \\
\hline
\end{tabular}

Authors' study based on: [13,66,67,70,82].

Therefore, the results of CTS in Polish cities confirm the results of foreign studies in terms of choosing the means of transport and the use of a car as a passenger mainly by women. It is worth noting that CTS carried out in Polish cities provide disaggregated information about non-motorized transportation (walking and cycling separately), which is not always recorded in foreign studies, e.g., national travel survey in Spain. Accurate data on the number of walking and the number of bicycle trips is very important-it shows the scale of the phenomenon and allow better planning to fulfil users' needs.

Similarly, as in the case of the previously analysed travel behaviours, the differences in the choice of a mode of transport depend on the stage of life of the two genders. This is shown in Figures 3 and 4 presenting results of the CTS for Cracow. People of school age, regardless of their gender, travel on foot or by car (in the case of smaller children) or by public transport and on foot (older pupils, students). In the case of older groups, which have completed education and started work, travelling by car becomes more common. This is true particularly for men, for whom very high rates of car travels are observed throughout the entire period of professional activity. In the same period, women rely most often on public transport. After retiring, the rate of travels on foot increases for both women and men, although nearly $1 / 3$ of men's trips still involve travelling by car.

When analysing the use of means of transport in more detail for age groups, it can be noticed that the smallest differences in mode choice occur for the age groups up to 24 years old, and the largest for the group-25-59/64 (men travel mainly by car and women choose different means). The age groups most dependent on the car are 39-49 for women and 30-49 for men. The age group 16-19 for both genders is the least dependent on the car and it is also the group that uses public transport to the greatest extent. Children up to 12 years use public transport the least and are in turn the group that most frequently travels on foot. Women aged 16-29 and men aged 25-49 travel by foot the least. The bicycle is chosen mainly by women aged 25-29 and men aged 16-39 as well as retired men.

The fact that in Poland the access to a car is a factor which lowers the percentage of women users is confirmed by the results of the latest CTS conducted in Wrocław, which indicate that in households comprising more than 1 person and which have only one car available, women only use the car in $30 \%$ of cases [13]. Lower car availability for women is, in turn, conditioned by the previously described historical and social factors (including the perception of a men as a driver/owner of a car and a woman as a passenger in a car).

Having a driving licence is another important factor-in 2015, 8 million women held a driving licence permitting the operation of private cars, which translated into $40 \%$ of all people [83]. At the same time, it can be seen that over the last few years, the percentage of women with a driving licence has grown significantly-by nearly 10 percentage points since 2001 . The changes are particularly visible in the case of middleaged women (45-65 years old), where the increase amounts to 19 percentage points. In the case of seniors (persons aged 65 and above), the share of female driving licence holders amounted to $8 \%$ in 2001, going up to $21 \%$ in 2015 . 


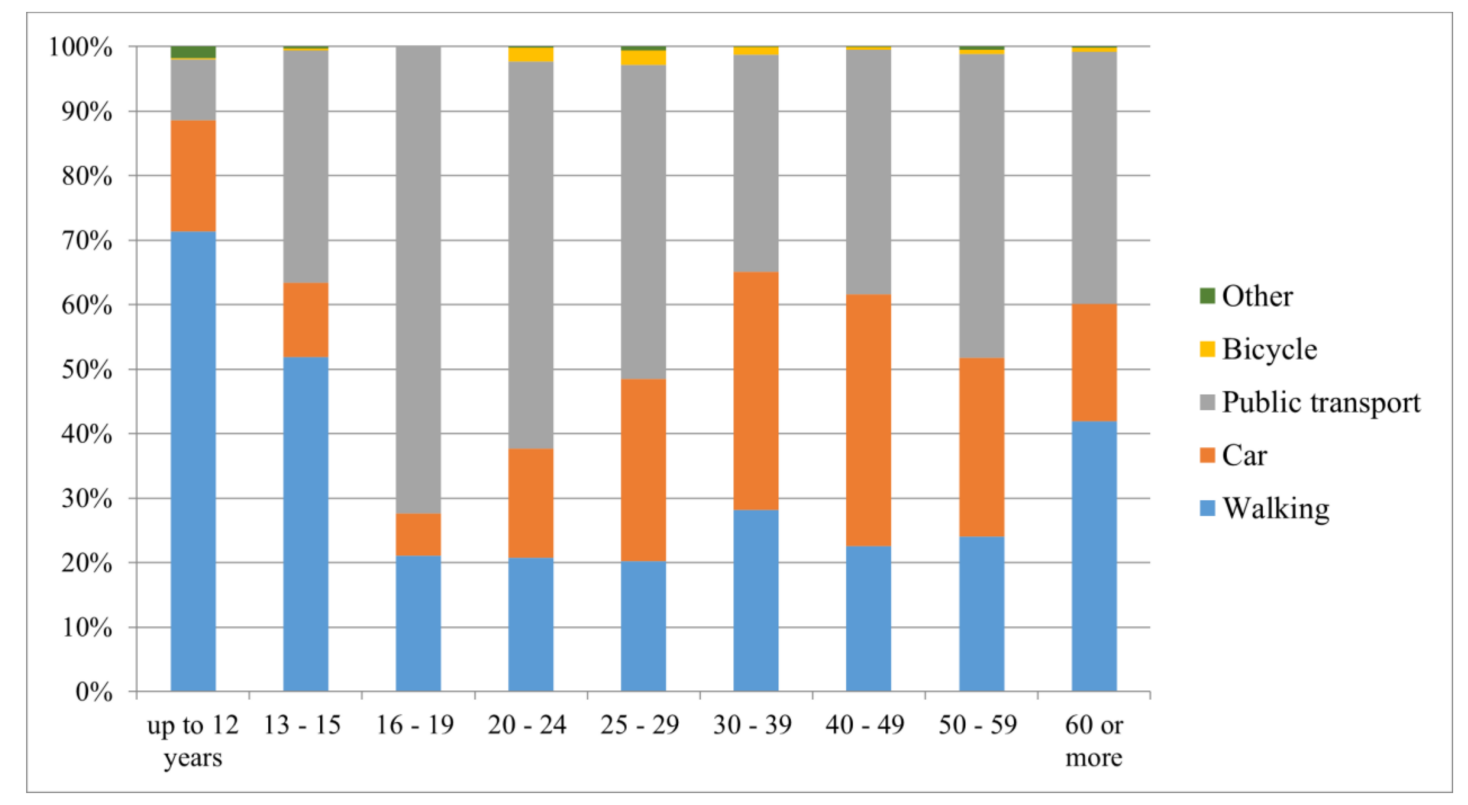

Figure 3. Modal split for women, by age, Cracow. Authors' study based on: [67].

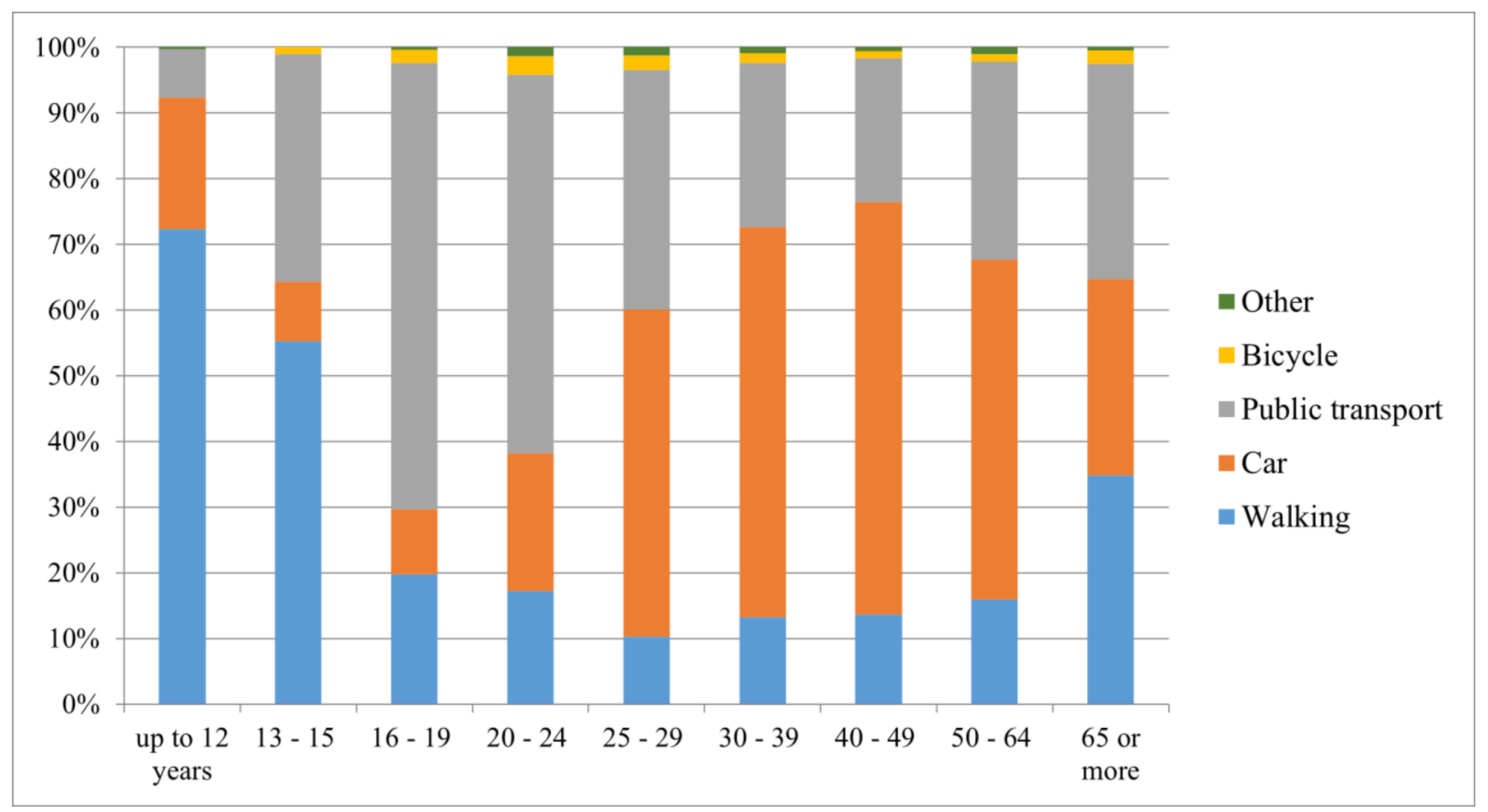

Figure 4. Modal split for men, by age, Cracow. Authors' study based on: [67].

\section{Awareness of Women's Mobility Needs and Adaptation of Transport to These Needs}

Considering the results of the study carried out for Polish cities, proving the existence of gender differences in travel, research was undertaken to examine the level of decision-makers' and planners' awareness of these differences and women's mobility needs. Considering these needs, a diagnosis of access to transportation and travel conditions by selected means of transport in analysed cities was made. 


\subsection{Awareness of the Gender Travel Issues}

The evidence of level of decision-makers' and planners' awareness of gender travel issues can be found in policies and plans currently in force, elaborated by analysed seven Polish cities (Warsaw, Cracow, Wrocław, Gdańsk, Szczecin, Kielce and Rzeszów). These policies and plans, listed in Table 9, concern directions of actions, mandatory standards and guidelines or recommendations for spatial and transport planning process.

The analysis of the cities' policies and strategic documents showed no mention of gender differences in travel in any document. The vast majority of documents do not consider the needs of women as an individual social group. If there is mention of women's mobility needs at all, it only applies to pregnant women as persons with reduced mobility (such a notation was found only in four documents), or to the needs of parents with children (found in nine documents). A little more attention is paid to the needs of people with disabilities and generally persons with reduced mobility. None of the documents took into account the needs of mentioned user groups (disabled, persons with reduced mobility, parents) to a greater extent, and least attention is paid to them in the City Development Strategies. The directions and good practices indicated in the documents, focused on the specific needs of people with disabilities or with reduced mobility, will also affect the perception and use of transport services and infrastructure by women. Although most documents do not mention caring functions of women as one of the additional reasons supporting the legitimacy of transport solutions, the solutions themselves are consistent with the needs of women in this respect. None of the analysed documents refer to gender discrimination in access to transport, either to gender equality.

Table 9. Analysed policies and plans.

\begin{tabular}{|c|c|}
\hline City & Document \\
\hline Warsaw & $\begin{array}{l}\text { Master Development Plan (2018) [84], Public Transport Sustainable Development Plan (2014) [85], Accessibility } \\
\text { guidelines and standards (2017) [86], Guidelines and standards for pedestrian infrastructure (2017) [87], Design and } \\
\text { implementation guidelines for pedestrian infrastructure (2017) [88]. }\end{array}$ \\
\hline \multirow{2}{*}{ Cracow } & City Development Strategy (2018) [89], Master Development Plan (2014) [90], Transport Policy (2016) [91], Public \\
\hline & $\begin{array}{l}\text { Master Development Plan (2018) [93], Mobility Policy (2013) [94], Public Transport Sustainable Development Plan } \\
\text { (2016) [95], Sustainable Urban Mobility Plan (2019) [96]. }\end{array}$ \\
\hline Gdańsk & $\begin{array}{l}\text { Master Development Plan (2018) [97], Mobility Policy (2013) [98], Public Transport Sustainable Development Plan } \\
\text { (2016) [99], Sustainable Urban Mobility Plan (2019) [100]. }\end{array}$ \\
\hline Szczecin & City Development Strategy (2011) [101], Master Development Plan (2012) [102], Public Transport Sustainable \\
\hline & Development Plan (2014) [103], Study of the sense of security of the inhabitants of the Szczecin City (2018) [104]. \\
\hline Kielce & City Development Strategy (2016) [105], Master Development Plan (2014) [106], Public Transport Sustainable \\
\hline Nлеге & Development Plan (2014) [107], Sustainable Urban Mobility Plan (2016) [108], Transport Policy (2006) [109]. \\
\hline Rzeszów & $\begin{array}{l}\text { Master Development Plan (2019) [110], Transportation Plan (2014) [111], Study on the public transport development } \\
\text { of the Rzeszów Functional Area (2015) [112]. }\end{array}$ \\
\hline
\end{tabular}

The results of this analysis highlight the low level of awareness of the gender travel issue among planners (who elaborated documents) and decision-makers (who approved documents), and its marginalization. Lack or low level of knowledge of gender issues in travel influences the way of collecting mobility data, causing the shortage of data connecting gender with mobility. It is also one of the reasons that transport systems are not fully adapted to the needs of women and persons with reduced mobility escorted by them.

\subsection{Transport Systems and Women's Mobility Needs}

This lack of adaptation of transport systems to women's needs and existence of barriers to transportation access for women is confirmed by the results of research and social initiatives which took place in analysed cities. For example, research conducted in 2017 in Cracow among nearly 200 women-caregivers of children and other persons with reduced mobility-showed that the following aspects of travel are very important to them: proper width of the sidewalk (without obstacles, either parked cars), even surface of the sidewalk, 
convenient and direct pedestrian access to the kindergarten/nursery/playground and public transport stop, as well as the availability of the low-floor public transport fleet with sufficiently wide entrances to the vehicle [10]. The results of the same research showed that in Cracow the majority of complaints regarding travel difficulties concern: the lack of or discontinuous sidewalks, poor condition of sidewalks, parked cars encroaching on the pedestrian walkway and lack of pedestrian crossings. The lack of the bicycle paths was also frequently highlighted by the caregivers. These issues are reflected in the initiatives led by the MamaTon Klub Mam Foundation, which aim to draw attention to the obstacles that can be encountered by mothers in the public space of the city of Cracow. The foundation organised, among others, the so-called "Baby Carriage Critical Mass" (October 2016) [11]. In the framework of this initiative, people with reduced mobility marched through the streets of a Cracow neighbourhood to attract public attention to the barriers and stumbling blocks that parents with little children, seniors, and people with disabilities come up against in the area.

Similar activities are carried out in Warsaw. In 2006 the MaMa foundation launched a campaign in Warsaw called "O Mamma Mia! I can't use a baby carriage here" for the adaptation of public space to baby carriages and wheelchairs. The first actions concerned a petition regarding low-floor public transport fleet [15], followed by auditing the railway and metro stations in two main transportation corridors. Volunteers with children in carriages checked, among other things, the adjustment of entrances to platforms and bus stops. In 2016, the same foundation, commissioned by the City Roads Authority in Warsaw, carried out an audit of 500 spots problematic for pedestrians [113].

The results of the diagnosis carried out in Warsaw [12] and Wrocław [13] shows that in both cities the great nuisance in everyday walking trips relates to trip comfort (obstacles such as cars parked on the sidewalks and the poor condition of sidewalks). An issue that needs improvement is the safety of walking and cycling in Polish cities. Every year, nearly 3,000 people die on Polish roads, 38\% of whom are pedestrians and cyclists [114]. In large cities, this group of vulnerable road users accounts for over $60 \%$ of all fatalities. The overall number of pedestrian deaths has been decreasing over the past few years, but the number of fatalities at pedestrian crossings is increasing. The number of cyclists involved in accidents is also increasing. In terms of cycling infrastructure, the number of kilometres of bicycle routes in Polish cities is steadily increasing, and Warsaw, Wrocław, Gdańsk and Cracow are leaders in this respect, but a problem of cycling infrastructure in Poland is its segmental nature, which makes it non-functional [14].

The results of available studies conducted in the analysed cities regarding the assessment of the public transport operation provide information about its condition and indicate areas for improvement. Research conducted in 2017 among passengers using public transport in Cracow showed that the general level of female satisfaction with its operation is lower than the general level of male satisfaction [2]. The largest quality gap (difference in expected versus actual assessments of the public transport operation) for both genders was identified for punctuality and travel time. There were also differences in the satisfaction and preferences of women and men in the context of security at the bus stop and in the vehicle, confirming the lack of a full sense of security among women. A similar problem exists in Wrocław, where, according to studies by Tubis et al. [18] travelling by night is considered dangerous or very dangerous mainly by women.

In studies conducted in 2015 in Rzeszów [16], the largest quality gap was noted for the availability of information about changes in the timetable, punctuality, and transfers from one public transport vehicle to another. A significant quality gap was also observed in facilities for the disabled, elderly and pregnant women. Meanwhile, in Kielce the lowest rated are the cost of public transport ticket, punctuality, frequency of travel and travel comfort [17]. In Gdańsk, more women than men indicate the increase in the transport offer ( $35 \%$ women vs. $29 \%$ men) and the expansion of tram lines ( $47 \%$ women vs. $42 \%$ men) as desired directions for the development of the transport system [68]. 
Information on the travel conditions of women and caregivers of persons with reduced mobility is also provided by research carried out by the Supreme Audit Office (Najwyższa Izba Kontroli (NIK)) in the field of accessibility of public transport and public space in Polish municipalities for people with disabilities and seniors. In terms of the availability of public transport, the 2016 NIK assessment showed that none of the 10 audited cities (including Rzeszów and Szczecin) did not provide disabled people with the option of using public transport at the same level of accessibility that is used by non-disabled people [115]. Unreliable analysis of the transport needs of residents, disregarding the right of people with disabilities to non-discriminatory access to public transport, in particular in terms of the availability of low-floor vehicle fleet and vehicle equipment, the availability of basic transport information and the organisation of space within stops caused that actions undertaken by cities in earlier years only slightly improved accessibility.

As regards the availability of public space (including pedestrian routes and green areas), the NIK audit carried out in 2018 in 24 municipalities (including Kielce and Wrocław) indicates that the measures taken did not improve enough the accessibility of public space for seniors and disabled people [116]. The communes recognised the needs and expectations regarding the improvement of accessibility; however, they did not consult the planned and implemented solutions with the target group, nor did they use universal design. This caused that the audited facilities were built, modernised or renovated in a way that did not ensure full accessibility for people with disabilities. In addition, most of the audited communes did not develop a strategy or plan to remove barriers from public space, which, in the opinion of the NIK, proves that the approach to improving the availability of public space for the elderly and disabled is not reliable.

\section{Discussion}

Unlike in Germany, Spain or the United Kingdom, in Poland there are no periodical studies of travel behaviour of the population carried out on a national scale. Gender travel behaviour patterns can only be analysed on the base of CTS conducted in larger cities, or of smaller-scale studies accompanying specific transportation projects. Previous foreign research focused on national or regional scale, possibly presenting a case study for a selected city or target group. Meanwhile, the comparison of CTS results for several different Polish cities, presented in this article, is an original approach to identifying differences in the travel behaviours of men and women and may have implications for urban policies and cities beyond the local case.

The results of CTS for Polish cities confirm most of the conclusions based on foreign research [31,39-42,46,47,52-54], but also provide new findings. As elsewhere, behavioural discrepancies between Polish women and men concern the trip purpose, the number of trips and the modes of transport. The identified differences in Polish conditions may be linked to a great extent to historical, cultural and social factors, which determined the role of women in the family, their position on the labour market and the level of the car use.

Although the perception of a woman's role within society has evolved over the centuries, which allowed Polish women to receive education, start work and to attain personal and professional goals, in present-day Poland, women are still perceived as the guardians of the hearth and home, responsible for keeping house and raising children. Despite the observed increase of women's involvement on the Polish labour market, there is still a significant disparity between female and male employment rates.

The participation in the labour market, as well as the family and care duties undertaken mostly by women, resulting from factors described above, are reflected in the trip purpose. Polish women, similar to women from other countries [31,40-42] travel to work less often than men, with most of their trips being connected to shopping, services or handling administrative matters. As the results of CTS for Cracow show, the trip purpose differences between the two genders become especially visible for the age group 25-49, after children are born and women tend to take on most of childcare responsibilities and housework. 
Results of foreign studies proves that the need to manage numerous responsibilities daily affects the number of trips $[39,41,47,52,53]$. In spite of the fact that no significant discrepancies have been noted in the general female and male Polish population, the above has been confirmed by analyses conducted in Warsaw and Gdańsk among people aged $25-59$, taking into account the main occupation of the population. It is primarily in this age group that women fulfil the historically and culturally assigned role, taking care of the home and other family members, and often working. This influences the frequency of travel-research results for these two cities not only prove that working women make more trips than working men (as we already know from the research by McGuckin and Nakamoto [48] and Hurez and Richer [49]), but also show differences in other groups (more trips made by female pensioners/women in receipt of disability benefits and, in the case of Gdańsk, unemployed women and women with another status). Another interesting result of the study is that male students are more mobile than female students.

As for the modes of transport, the CTS studies for Polish cities showed that men use cars more often and that the percentage of trips undertaken by them using this means of transport remains high over the entire period of professional activity. In the same period, women rely most often on public transport. They are often more prone to travelling on foot and if they do use a car-it is usually as passengers. As the results of CTS for Cracow show, these differences are mostly visible for the age group 25-59 (64 in case of men). Moreover, the age groups most dependent on the car are 39-49 for women and 30-49 for men. The age group16-19 for both women and men is the least dependent on the car and it is also the group that uses public transport to the greatest extent. Children up to 12 years most frequently travel on foot, and women aged 16-29 as well as men aged 25-49 travel by foot the least. Another interesting result of the study is that after retiring, the rate of travels on foot increases for both women and men, although nearly $1 / 3$ of men's trips still involve travelling by car.

A lower share of car use by women can be associated with the still persistent in Poland stereotype of the car as a masculine attribute and with its limited availability to women (as evidenced by the CTS conducted in Wrocław), also resulting from and with a lower percentage of women holding a driving licence. At the same time, the increasing share of female driving licence holders in Poland is a consequence of not only the cultural changes and greater involvement of women in professional activities but also of the growing wealth of society thanks to which a private car has ceased to be a luxury in the last two decades. When analysing the results on the transport mode it is worth noting that CTS carried out in Polish cities provide disaggregated information about non-motorized transportation (walking and cycling separately), which is not always recorded in foreign studies, for example in national travel survey in Spain [43]. Accurate data on the number of walking and bicycle trips is very important-it shows the scale of the phenomenon and allows better planning to fulfil users' needs.

The process of pushing women out of prestigious and well-paid jobs into occupations traditionally seen as "female", especially conspicuous in Poland in the communist era (1956-89), still manifests itself today in the high percentage of Polish women working in lower-paying industries and their under-representation in top managerial positions. This results in discrepancies between women's and men's earnings, although Poland is one of the EU states with a lower unadjusted Gender Pay Gap [21]. Unfortunately, analyses of the travel logs sourced from the available CTS studies for Polish cities do not allow us to confirm whether the lower use of cars among women can be linked to their financial standing resulting from lower earnings (as suggested by results of foreign studies $[4,41]$ ). Some CTS asked respondents about the total monthly income of their household, but without taking into consideration the individual family members and their gender. 
Results of foreign studies indicate too that gender travel behaviour differences also concern the length of trips-distances travelled by women are shorter than those travelled by men $[38,50,51,61,62]$. Meanwhile, Polish studies focus on the travelling distance on very rare occasions, so it is hard to verify the above claims based on the results of research conducted in Poland.

The shortage of data connecting gender with mobility in Poland is a consequence of unfamiliarity with the problem and, in some cases, its marginalization. This marginalization of gender issues results from historical burdens, culture, and the current political situation, which therefore should not only be seen as factors that may explain travel behaviour, but also as barriers to achieving the equity in access to transport. As the results of our study show, the awareness of gender-differentiated travel behaviour is very low in Poland and Polish cities, planning their spatial and transport systems, practically do not take into account the needs of women and consider the needs of persons escorted by them only to a limited extent. Issues of gender travel differences and gender equality in access to transport do not appear in the strategic documents. Meanwhile, the awareness of the correlations between gender and travel behaviours and the needs of women and men is very useful in planning sustainable mobility — both to ensure social equality (through social participation, encouraging women to participate in planning, through improvement of transport access and travelling conditions and spatial planning taking into account women's needs), and to shape the desired travel behaviours (e.g., planning activities aimed at reducing the number of car trips with the focus on working men). Having in mind, that discussion on gender equity does not exist in Polish governmental political discourse, it is important to raise the scientific and professional community's awareness of the necessity of including gender aspects into plans, projects and strategies. The awareness of the problem should be especially raised among Polish decision-makers and planners.

The analyses conducted as a part of this article reveal that a high percentage of women travel on public transport and on foot. These means are also mainly used by children and the elderly, very often escorted by women. Meanwhile, in Poland these modes are not yet adapted to the needs of women and persons with reduced mobility. There is a need to improve walking infrastructure and increase the quality of public transport service. Similarly, in order to encourage more Polish women to use bicycles, the bicycle transport system should be improved.

\section{Conclusions}

The results of this study confirm that travel behavioural discrepancies between women and men concern the trip purpose, the number of trips and the modes of transport. Additionally, our findings indicate that the greatest differences in trip purposes are observed for people aged 25-49. It is in this age group that women tend to take on most childcare responsibilities and housework, making significantly more trips for shopping or to handle administrative matters, while men travel mostly for work. In relation to the number of trips for the age group 25-59, we demonstrated, that the differences may be significant if the main occupation of the population is taken into account. Results for Warsaw and Gdańsk indicate that male students are more mobile than female students, and a greater number of trips are made by women going to work, working at home, pensioners and women in receipt of disability benefits. The new findings on transport mode choice indicate that the differences are mostly visible for the people aged 25-59 (64 in case of men). Moreover, the groups most dependent on the car are 39-49 for women and 30-49 for men. It can be concluded that when planning activities aimed at changing travel behaviour towards reducing the number of car trips, focus should be on working men. The age group 16-19 for both women and men is the least dependent on the car and it is also the group that uses public transport to the greatest extent. Another interesting result is that after retiring, the rate of travels on foot increases for both women and men, although nearly $1 / 3$ of men's trips still involve travelling by car. 
The lack of proper data from the available CTS for Polish cities do not allow us to carry out analysis for the trip length, to confirm whether the lower car use by women can be linked to their financial standing resulting from lower earnings. Moreover, Polish domestic studies rely on different attributes to describe households, population, or journeys, which makes it even more difficult or, often, impossible to diagnose certain differences according to gender. This applies, for example, to the trip purpose aspect-studies conducted in some Polish cities are based on a more general division of trip purposes, without identifying those which have been proven by foreign studies to be more typical for women (e.g., child escorting).

The differences we identified may be explained to a great extent by historical, cultural, and social factors, which determined the role of Polish women in the family, their position in the labour market and the level of car use. These historical burdens and the political situation can be also seen as barriers to achieving equal access to transport, and moreover-can cause other types of barriers (e.g., related to social roles, economic situation or infrastructure) to go unnoticed or become marginalized. Lack or low level of awareness of gender travel issues, that we identified for Polish cities, not only influences the way of collecting mobility data, causing the shortage of data, but can be also seen as ane of the reasons that Polish transport systems are not fully adapted to the needs of women and persons with reduced mobility.

The directions for future research should provide focus on gender travel behaviour in terms of the main occupation and family responsibilities, the situation of single mothers, the availability of social benefits provided by the government or the type of disability. Attention could be paid to the trip chains in Poland, since this issue has not been studied in Polish conditions. More light should be also shed on the needs of women living in poorly urbanised areas where the access to alternative modes of transport is much more limited than in cities and where the scattering of public utility buildings does not make it any easier to manage daily family and care responsibilities.

Author Contributions: The research was designed and theoretically framed by both researchers. The data on historical and cultural issues as well as public policies was gathered and analysed by S.P.-O. The data on labour market, travel behaviours and transport systems in Polish cities was gathered and analysed by K.N.H. Both authors prepared the original draft of the paper, made the review and contributed to the final version of the manuscript with concluding remarks. All authors have read and agreed to the published version of the manuscript.

Funding: This research received no external funding.

Data Availability Statement: 3rd Party Data. Restrictions apply to the availability of these data. Data was obtained from the Municipalities and the Transport Authorities of analysed Polish cities and are available from the authors with the permission of the Municipalities and the Transport Authorities.

Conflicts of Interest: The authors declare no conflict of interest.

\section{References}

1. Olmo Sánchez, M.I.; Maeso González, E. Gender Differences in Commuting Behavior: Women's Greater Sensitivity. Transp. Res. Proc. 2016, 18, 66-72. [CrossRef]

2. Bryniarska, Z.; Puławska-Obiedowska, S. Analysis of the perception of the quality of public transport among women and men in Krakow. Transp. Miej. I Reg. 2020, 5, 15-20.

3. Fidelis, M. Women, Communism, and Industrialization in Postwar Poland; Cambridge University Press: Cambridge, UK, 2010.

4. Umińska-Keff, B.; Graff, A.; Hutnik, S. Women in a Period of 1989-2009; Przedstawicielstwo Fundacji im. Heinricha Bölla: Warszawa, Poland, 2009; pp. 6-55.

5. TNS Polska. Poles on The Role of Women and Men in the Family in 1994 and 2014; TNS Polska: Warsaw, Poland, 2014.

6. GUS. Reconciliation between Work and Family Life in 2018; GUS: Warsaw, Poland, 2019.

7. Melosik, Z. Car, identity and cultural gender. Studia Eduk. 2016, 36, 73-86. [CrossRef]

8. GUS. Religious Life in Poland. Social Cohesion Survey Results 2018; GUS: Warsaw, Poland, 2018.

9. Szwed, A. Typy legitymizacji w wypowiedziach hierarchów kościoła rzymskokatolickiego w Polsce na temat gender i praw reprodukcujnych. Studia Socjol. 2019, 3, 81-108. [CrossRef] 
10. Rogala, S. Transportation Systems Design Taking into Account the Needs of People with Restricted Mobility, Especially Persons with Children. Master's Thesis, Cracow University of Technology, Krakow, Poland, 2017.

11. Płuciennik, O.; Cypryś-Ławniczak, K. 1st Baby Carriage Critical Mass; Report from the March Through the Streets af a Neighbourhood No. 4; The Office of Mobility and Transport Policy: Kraków, Poland, 2016.

12. The Office of Mobility and Transport Policy. Report on Pedestrian Traffic in Warsaw; The Office of Mobility and Transport Policy: Warsaw, Poland, 2018.

13. Comprehensive Travel Studies in Wrocław and the Surrounding Area 2018. Available online: http://bip.um.wroc.pl/artykul/56 5/37499/kompleksowe-badania-ruchu-we-wroclawiu-i-otoczeniu-kbr-2018 (accessed on 19 June 2019).

14. Dzieniowska, A.; Dolińska, I. Bicycle transport, complementary to the transport system of the polish cities. Transp. Samoch. 2017, 4, 41-50.

15. Public Transport. A Woman Excluded. Gender and the City Spatial Planning. Available online: http://www.transportpubliczny.pl/wiadomosci/kobieta-wykluczona-czyli-co-ma-plec-do-planowania-przestrzennego-miasta-1908.htm (accessed on 20 October 2020).

16. Zimon, G.; Gosik, B. Urban logistics evaluation of collective transport on the example of Tomaszów Mazowiecki and Rzeszów. Mod. Manag. Rev. 2015, 22, 197-209.

17. Rubika Consulting. Comprehensive Travel Studies in Kielce; Rubika Consulting: Kielce, Poland, 2015.

18. Tubis, A.; Poskart, A.; Rydlewski, M. Risk assessment of traveling by public transport in Wrocław, taking into account security and logistics aspects. Prace Naukowe Politechniki Warszawskiej Transp. 2018, 120, 415-427.

19. Puławska, S.; Żakowska, L. Woman perception on building more sustainable transport environment. In Proceedings of the 5th International Conference on Women's Issues in Transportation, Paris, France, 14-16 April 2014; pp. 697-701.

20. Samek Lodovici, M.; Pesce, F.; Malgieri, P.; Maffi, S.; Rosa, C. Gender Equality. The Role of Women in the Green Economy: The Issue of Mobility; European Parliament: Brussels, Belgium, 2012. Available online: http://www.trt.it/wp/wp-content/uploads/2012/05/ PT_12_-Gender_mobility.pdf (accessed on 20 October 2020).

21. Eurostat. Available online: https:/ / ec.europa.eu/eurostat/data/database (accessed on 19 June 2019).

22. CIVITAS WIKI 2014. Policy Note: Smart Choices for Cities. Gender Equality and Mobility: Mind the Gap! Available online: https:/ / civitas.eu/sites/default/files/civ_pol-an2_m_web.pdf (accessed on 20 October 2020).

23. Schulze, E.; Gergoric, M. Maternity, Paternity and Parental Leave: Data Related to Duration and Compensation Rates in the European Union. 2015. Available online: http:/ / www.europarl.europa.eu/RegData/etudes/STUD/2015/509999/IPOL_STU(20 15)509999_EN.pdf (accessed on 20 October 2020).

24. Sweet, M.; Kanaroglou, P. Gender differences: The role of travel and time use in subjective well-being. Transport. Res. F Traf. 2016, 40, 23-34. [CrossRef]

25. Scheiner, J. School trips in Germany: Gendered escorting practices. Transp. Res. A Pol. 2016, 94, 76-92. [CrossRef]

26. EIGE 2011. Reconciliation of Work and Family Life as a Condition of Equal Participation in the Labour Market: Report. Available online: https: / / eige.europa.eu/node/293 (accessed on 19 June 2019).

27. Rosenbloom, S.; Burns, E. Gender differences in commuter travel in Tucson: Implications for travel demand management programs. Transp. Res. Rec. 1993, 1404, 82-90.

28. Best, H.; Lanzendorf, M. Division of labour and gender differences in metropolitan car use: An empirical study in Cologne. Germany. J. Transp. Geogr. 2005, 13, 109-121. [CrossRef]

29. Tilley, S.; Houston, D. The gender turnaround: Young women now travelling more than young men. J. Transp. Geogr. 2016, 54, 349-358. [CrossRef]

30. Adeel, M.; Yeh, A.G.O.; Zhang, F. Gender inequality in mobility and mode choice in Pakistan. Transportation 2017, 44, 1519-1534. [CrossRef]

31. Craig, L.; van Tienoven, T.P. Gender, mobility and parental shares of daily travel with and for children: Across-national time use comparison. J. Transp. Geogr. 2019, 76, 93-102. [CrossRef]

32. Scheiner, J. Gendered key events in the life course: Effects on changes in travel mode choice over time. J. Transp. Geogr. 2014, 37, 47-60. [CrossRef]

33. Chakrabarti, S.; Joh, K. The effect of parenthood on travel behavior: Evidence from the California Household Travel Survey. Transp. Res. A Pol. 2019, 120, 101-115. [CrossRef]

34. Uteng, T.P.; Cresswell, T. (Eds.) Gendered Mobilities; Ashgate: Farnham, UK, 2008.

35. Basarić, V.; Vujičić, A.; Mitrović Simić, J.; Bogdanović, V.; Saulić, N. Gender and Age Differences in the Travel Behavior-A Novi Sad Case Study. Transp. Res. Proc. 2016, 14, 4324-4333. [CrossRef]

36. Mejia-Dorantes, L. An example of working women in Mexico City: How can their vision reshape transport policy? Transp. Res. A Pol. 2018, 116, 97-111. [CrossRef]

37. Pazy, A.; Salomon, I.; Pintzov, T. The impacts of women's careers on their commuting behavior: A case study of Israeli computer professionals. Transp. Res. A Pol. 1996, 30, 269-286. [CrossRef]

38. Frändberg, L.; Vilhelmson, B. More or less travel: Personal mobility trends in the Swedish population focusing gender and cohort. J. Transp. Geogr. 2011, 19, 1235-1244. [CrossRef]

39. Susilo, Y.O.; Liu, C.; Börjesson, M. The changes of activity-travel participation across gender, life-cycle, and generations in Sweden over 30 years. Transportation 2019, 46, 793-818. [CrossRef] 
40. Schwanen, T. Gender differences in chauffeuring children among dual-earner families. Prof. Geogr. 2007, 59, 447-462. [CrossRef]

41. Motte-Baumvol, B.; Bonin, O.; Belton Chevallier, L. Gender differences in children escorting practices among dual-earners families in the Paris Region. In Proceedings of the 5th International Conference on Women's Issues in Transportation, Paris, France, 14-16 April 2014; pp. 81-93.

42. Sicks, K.; Scheiner, J.; Holz-Rau, C. Born to shop? Gender-specific activity travel in Germany. In Proceedings of the 5th International Conference on Women's Issues in Transportation, Paris, France, 14-16 April 2014; pp. 121-131.

43. Dirección General de Programación Económica del Ministerio de Fomento 2008. Encuesta de Movilidad de las Personas Residentes en España 2006-2007. Available online: https:/ / www.fomento.gob.es/NR/rdonlyres/2D1D40A2--3417-4C74-AF3F-D22D3A161F9 6/110679/Movilia20062007.pdf (accessed on 20 October 2020).

44. Department for Transport. National Statistics. National Travel Survey: 2017. Available online: https://www.gov.uk/government/ statistics / national-travel-survey-2017 (accessed on 19 June 2019).

45. Turner, J.; Grieco, M. Gender and time poverty. The neglected social policy implications of gendered time, transport and travel. Time Soc. 2000, 9, 129-136. [CrossRef]

46. Matthies, E.; Kuhn, S.; Klöckner, C.A. Travel mode choice of women: The result of limitation, ecological norm, or weak habit? Env. Behav. 2002, 34, 163-177. [CrossRef]

47. Li, H.; Guensler, R.; Ogle, J. Comparing women's and men's morning commute trip chaining in Atlanta, Georgia, by using instrumented vehicle activity data. In Proceedings of the Conference on Research on Women's Issues in Transportation, Chicago, IL, USA, 18-20 November 2004; Volume 2, pp. 14-20.

48. McGuckin, N.; Nakamoto, Y. Differences in trip chaining by men and women. In Proceedings of the Conference on Research on Women's Issues in Transportation, Chicago, IL, USA, 18-20 November 2004; Volume 2, pp. 49-56.

49. Hurez, C.; Richer, C. Does the city's pulse beat at the same rate for men and women? Gender time-geography. In Proceedings of the 5th International Conference on Women's Issues in Transportation, Paris, France, 14-16 April 2014; pp. 59-69.

50. Scheiner, J.; Holz-Rau, C. Women's complex daily lives: A gendered look at trip chaining and activity pattern entropy in Germany. Transportation 2017, 44, 117-138. [CrossRef]

51. Ng, W.-S.; Acker, A. Understanding urban travel behaviour by gender for efficient and equitable transport policies. In International Transport Forum Discussion Paper, No. 2018-01; Organisation for Economic Co-operation and Development (OECD), International Transport Forum: Paris, France, 2018. [CrossRef]

52. Olmo Sánchez, M.I.; Maeso González, E. Application of gender indicators to urban mobility analysis. In Proceedings of the PANAM 2014 Conference, Santander, Spain, 11-13 June 2014. [CrossRef]

53. Olmo Sánchez, M.I.; Maeso González, E. Travel patterns, regarding different activities: Work, studies, household responsibilities and leisure. Transp. Res. Proc. 2014, 3, 119-128. [CrossRef]

54. Leslie, E.; Kremer, P.; Toumbouroua, J.W.; Williams, J.W. Gender differences in personal, social and environmental influences on active travel to and from school for Australian adolescents. J. Sci. Med. Sport 2010, 13, 597-601. [CrossRef]

55. The Gallup Organization. Attitudes on issues related to EU transport policy. 2007. Available online: http://ec.europa.eu/ commfrontoffice/publicopinion/flash/fl_206b_en.pdf (accessed on 20 October 2020).

56. TNS Opinion \& Social. Attitudes of European towards urban mobility. 2013. Available online: http://ec.europa.eu/ commfrontoffice/publicopinion/archives/ebs/ebs_406_en.pdf (accessed on 20 October 2020).

57. Sa'ar, A.; Yahia-Younis, T. Masculinity in crisis: The case of Palestinians in Israel. Br. J. Middle East. Stud. 2008, 35, 305-323. [CrossRef]

58. Prati, G. Gender equality and women's participation in transport cycling. J. Transp. Geogr. 2018, 66, 369-375. [CrossRef]

59. Sovacool, B.K.; Kester, J.; Noel, L.; de Rubens, G.Z. Are electric vehicles masculinized? Gender, identity, and environmental values in Nordic transport practices and vehicle-to-grid (V2G) preferences. Transp. Res. Part. D Transp. Environ. 2019, 72, 187-202. [CrossRef]

60. Carteni, S. The acceptability value of autonomous vehicles: A quantitative analysis of the willingness to pay for shared autonomous vehicles (SAVs) mobility services. Transportation Research Interdisciplinary Perspectives. 2020, 8, 1-13. [CrossRef]

61. Hjorthol, R.; Vagane, L. Allocation of tasks, arrangement of working hours and commuting in different Norwegian households. J. Transp. Geogr. 2014, 35, 75-83. [CrossRef]

62. Soria-Lara, J.A.; Marquet, O.; Miralles-Guasch, C. The influence of location, socioeconomics, and behaviour on travel-demand by car in metropolitan university campuses. Transport. Res. D Tr. E. 2017, 53, 149-160. [CrossRef]

63. Infas, DLR, IVT Research and Infas 360. Mobilität in Deutschland. Bonn. Available online: http://www.mobilitaet-in-deutschland. de/pdf/MiD2017_Ergebnisbericht.pdf (accessed on 20 October 2020).

64. Trafik Analys. The Swedish National Travel Survey 2015-2016. Available online: https:/ /www.trafa.se/globalassets/statistik/ resvanor/2016/rvu_sverige_2016-reviderad-7-juli.pdf (accessed on 20 October 2020).

65. Tęcza, J. Report on the Situation of Parents on the Labour Market. 2013. Available online: http://www.ffi.org.pl/pliki/file/PI/E1 \%20Dok1\%20Rap\%20na\%20tem\%20syt\%20rodzic\%C3\%B3w\%20na\%20rynku\%20pr.pdf (accessed on 20 October 2020).

66. PBS Sp. z o.o. Study of Travel Behavior of Warsaw Residents; Politechnika Krakowska: Kraków, Poland; Politechnika Warszawska: Warsaw, Poland, 2015. 
67. PBS Sp. z o.o.; Jan Friedberg-Projektowanie i doradztwo w zarządzaniu; EKKOM Sp. z o.o.; International Management Services Sp. $\mathrm{z}$ o.o. Research on Travel Behavior of the Inhabitants of the Krakow Metropolitan Area; Politechnika Krakowska: Kraków, Poland, 2013.

68. Gdańsk Travel Studies. Data obtained from the Gdańsk Development Office, 2016; (unpublished work).

69. Comprehensive Travel Studies in Szczecin. Data obtained from the City of Szczecin, 2016; (unpublished work).

70. Travel Studies in Rzeszów. Data Obtained from the City of Rzeszów, Rzeszów, Poland, 2016; (unpublished work).

71. Kamprowski, R. The place and role of a woman in the family over the centuries. From Antiquity to World War, I. Outline of the problem. Refleksje. Pismo Nauk. Stud. I Dr. Wnpid Uam 2011, 4, 33-41. [CrossRef]

72. Ward, J. Women in Medieval Europe: 1200-1500; Routledge: London, UK, 2002.

73. Augustyniak, U. History of Poland 1572-1795; Wydawnictwo Naukowe PWN: Warszawa, Poland, 2008.

74. Mrozik, A. To evoke from silence: The history of women in the PRL: Women in the history of the PRL. Teksty Drugie Teor. Lit. Kryt. Interpret. 2011, 4, 112-119. Available online: http:/ / rcin.org.pl/Content/48083/WA248_65341_P-I-2524_mrozik-wywolac.pdf (accessed on 20 October 2020).

75. Pew Research Center. 5 Facts about Catholics in Europe. Available online: https://www.pewresearch.org/fact-tank/2018/12/19 /5-facts-about-catholics-in-europe/ (accessed on 20 February 2021).

76. Halman, L.; Riis, O. Religion in Secularizing Society. The Europeans' Religion at the End of the 20th Century; Brill: Leiden, The Netherlands, 2002.

77. GUS. Women and Men on the Labour Market; GUS: Warsaw, Poland, 2018.

78. GUS. Women and Men on the Labour Market; GUS: Warsaw, Poland, 2012.

79. GUS. Women and Men on the Labour Market; GUS: Warsaw, Poland, 2016. Available online: https://stat.gov.pl/files/gfx/ portalinformacyjny/pl/defaultaktualnosci/5821/1/6/1/kobiety_i_mezczyzni_2016.pdf (accessed on 20 October 2020).

80. Centre for Research and Analyses of the Labour Market. Differences in Wages and Salaries of Women and Men in Poland in 2016; Centre for Research and Analyses of the Labour Market: Bydgoszcz, Poland, 2018.

81. TNS Polska. Report on Factors Affecting Transport Physical Activity of POLES; TNS Polska: Warsaw, Poland, 2015.

82. Ove Arup and Partners International. CTS in Szczecin; Ove Arup and Partners International: Warszawa, Poland, 2011.

83. Central Register of Vehicles and Drivers, CEPIK. Available online: http://www.cepik.gov.pl/statystyki (accessed on 20 October 2020).

84. Study of Conditions and Directions of Spatial Development of the Capital City of Warsaw as Amended*; Resolution No. LXII/1667/2018 of the Council of the Capital City of Warsaw Annex No. 1; The Council of the Capital City of Warsaw: Warszawa, Poland, 2018.

85. Road and Transport Office and the City Transport Authority. Plan for Sustainable Development of Public Transport for the Capital City of Warsaw, Including Public Transport Organized on the Basis of Agreements with Neighboring Municipalities; Road and Transport Office and the City Transport Authority: Warsaw, Poland, 2014.

86. App. 1. Accessibility Guidelines and Standards; Ordinance No. 1682/2017 of the Mayor of the Capital City of Warsaw Regarding the Creation of Available Space in the Capital City of Warsaw, Including Pedestrian Infrastructure, with Particular Emphasis on People with Reduced Mobility and Perception; The Mayor of the Capital City of Warsaw: Warsaw, Poland, 2017.

87. App. 2. Guidelines and Standards for Pedestrian Infrastructure; Ordinance No. 1682/2017 of the Mayor of the Capital City of Warsaw Regarding the Creation of Available Space in the Capital City of Warsaw, Including Pedestrian Infrastructure, with Particular Emphasis on People with Reduced Mobility and Perception; The Mayor of the Capital City of Warsaw: Warsaw, Poland, 2017.

88. App. 3. Design and Implementation Guidelines for Pedestrian Infrastructure in the Capital City in Warsaw; Ordinance No. $1682 / 2017$ of the Mayor of the Capital City of Warsaw Regarding the Creation of Available Space in the Capital City of Warsaw, Including Pedestrian Infrastructure, with Particular Emphasis on People with Reduced Mobility and Perception; The Mayor of the Capital City of Warsaw: Warsaw, Poland, 2017.

89. City Development Strategy. Here I Want to Live. Cracow 203; Resolution No. XCIV/2449/18 of the Council of the City of Cracow; The Council of the City of Cracow: Cracow, Poland, 2018.

90. Study of Conditions and Directions of Spatial Development of the City of Cracow; Resolution No. CXII/1700/14 of the Council of the City of Cracow; The Council of the City of Cracow: Cracow, Poland, 2014.

91. Transport Policy for the City of Cracow for 2016-2025; Resolution No. XLVII/848/16 of the Council of the City of Cracow; The Council of the City of Cracow: Cracow, Poland, 2016.

92. Public Transport Sustainable Development Plan for Cracow; Resolution No. LX/774/08 of the Council of the City of Cracow; The Council of the City of Cracow: Cracow, Poland, 2008.

93. Study of Conditions and Directions of Spatial Development of the City of Wroctaw; Resolution No. L/1177/18 of the Council of the City of Wrocław; The Council of the City of Wrocław: Wrocław, Poland, 2018.

94. Mobility Policy for the City of Wroctaw; Resolution No. XLVIII/1169/13 of the Council of the City of Wrocław; The Council of the City of Wrocław: Wrocław, Poland, 2013.

95. Public Transport Sustainable Development Plan for the City of Wrocław for 2016-2022; Resolution No. XXXIV/713/16 of the Council of the City of Wrocław; The Council of the City of Wrocław: Wrocław, Poland, 2016.

96. Sustainable Urban Mobility Plan for the City of Wroctaw; Resolution No. VIII/194/19 of the Council of the City of Wrocław; The Council of the City of Wrocław: Wrocław, Poland, 2019. 
97. Development Strategy of the City of Gdańsk 2030 Plus; Resolution No. LVII/1327/14 of the Council of the City of Gdańsk; The Council of the City of Gdańsk: Gdańsk, Poland, 2014.

98. Study of Conditions and Directions of Spatial Development of the City of Gdansk; Resolution No. XII/218/19 of the Council of the City of Gdańsk; The Council of the City of Gdańsk: Gdańsk, Poland, 2019.

99. REFUNDA; Sp. z o.o. Public Transport Sustainable Development Plan for the District of Gdańsk; The City of Gdańsk.: Gdańsk, Poland, 2016.

100. Sustainable Urban Mobility Plan for the City of Gdańsk 2030; Resolution No. 1615 of the Council of the City of Gdańsk; The Council of the City of Gdańsk: Gdańsk, Poland, 2018.

101. App. 1. Szczecin Development Strategy 2025; Resolution No. XIV/320/11 of the Szczecin City Council regarding the adoption of the Szczecin Development Strategy 2025; The Szczecin City Council: Szczecin, Poland, 2011.

102. Study of Conditions and Directions of Spatial Development of the City of Szczecin; Resolution No. XVII/470/12 RM of the Szczecin City Council; The Szczecin City Council: Szczecin, Poland, 2012.

103. City of Szczecin Sustainable Public Transport Development Plan for the City of Szczecin for 2014-2025; The Szczecin City Council: Szczecin, Poland, 2014.

104. Laboratory of Research on the Security of Local Government Communities. Study of the Security Sense of the Inhabitants of the Szczecin City 2018; Laboratory of Research on the Security of Local Government Communities: Szczecin, Poland, 2018.

105. Development Strategy of the City of Kielce 2007-2020 Update; Resolution No. XXXI/613/2016 of the Kielce City Council; The Kielce City Council: Kielce, Poland, 2016.

106. App. 1. Study of Conditions and Directions of Spatial Development; Resolution No. LXVII/1217/2014 of the Kielce City Council; The Kielce City Council: Kielce, Poland, 2014.

107. Bauer, M.; Dźwigon, W.; Szarata, A.; Rudnicki, A.; Pyzik, M. Transport Plan for the Kielce City and Adjacent Communes Forming Joint Public Transport; The Kielce City Council: Kielce, Poland, 2013.

108. Szarata, A. Mobility Plan for the City of Kielce and the Kielce Functional Area; The City of Kielce: Kielce, Poland, 2016.

109. Rudnicki, A. Sustainable Development Transport Policy Project for the City of Kielce and the Kielce Metropolitan Area; The City of Kielce: Kielce, Poland, 2006.

110. Resolution No. XXXVII/113/2000 of the Rzeszów City Council (Updated); Annex 9; The Rzeszów City Council: Rzeszów, Poland, 2019.

111. City of Rzeszów. Plan for Sustainable Development of Public Transport for 2014-2020 for the City of Rzeszów and Neighbouring Municipalities That Have Concluded Agreements with the City of Rzeszów Regarding the Public Transport Organization; The City of Rzeszów: Rzeszów, Poland, 2014.

112. Annex 1: Study of the Development of Public Transport of the Rzeszów Functional Area; Resolution No XVI/319/2015 of the Rzeszów City Council; The Rzeszów City Council: Rzeszów, Poland, 2015.

113. Urban Roads Authority. We Commissioned an Audit of 500 Problematic Pedestrian Areas. Available online: https://zdm.waw. pl/aktualnosci/zlecilismy-audyt-500-problematycznych-miejsc-dla-pieszych (accessed on 20 October 2020).

114. Urban Policy Observatory. Working Report of the Expert Group of the Urban Policy Congress on Transport and Mobility. Available online: http:/ / obserwatorium.miasta.pl/wp-content/uploads/2019/11/2019--11-06_KPM_TRANSPORT-raportroboczy.pdf (accessed on 20 October 2020).

115. NIK. Accessibility of Public Collective Transport for Disabled People in Cities with Poviat Rights; NIK: Warszawa, Poland, 2015.

116. NIK. Accessibility of Public Space for the Elderly and Disabled People; NIK: Warszawa, Poland, 2018. 